\title{
Mineralogical control on the magnetic anisotropy of lavas and ignimbrites: a case study in the Caviahue-Copahue field (Argentina)
}

\author{
Thiago R. Moncinhatto ${ }^{\odot},{ }^{1}$ Maurício B. Haag, ${ }^{2}$ Gelvam A. Hartmann ${ }^{\odot},{ }^{3}$ Jairo F. Savian, ${ }^{2}$ \\ Wilbor Poletti ${ }^{4}$ Carlos A. Sommer, ${ }^{2}$ Alberto T. Caselli ${ }^{5}$ and Ricardo I. F. Trindade ${ }^{1}$ \\ ${ }^{1}$ Instituto de Astronomia, Geofísica e Ciências Atmosféricas, Universidade de São Paulo, Rua do Matão 1226, 05508-090 São Paulo, SP, Brazil. \\ E-mail: rmthiago@iag.usp.br \\ ${ }^{2}$ Instituto de Geociências, Universidade Federal do Rio Grande do Sul, Av. Bento Gonçalves 9500, $91501-970$ Porto Alegre, RS, Brazil \\ ${ }^{3}$ Instituto de Geociências, Universidade Estadual de Campinas, Rua Carlos Gomes 250, 13083-855 Campinas, SP, Brazil \\ ${ }^{4}$ Instituto de Ciência e Tecnologia, Universidade Federal dos Vales do Jequitinhonha e Mucuri, Rodovia MGT-367, 5000, 39100-000 Diamantina, MG, Brazil. \\ ${ }^{5}$ Laboratorio de Estudio y Seguimiento de Volcanes Activos, Universidad Nacional de Río Negro, Roca 1242, 8332 G. Roca, Rio Negro, Argentina
}

Accepted 2019 October 19. Received 2019 October 11; in original form 2019 May 22

\begin{abstract}
SUMMAR Y
Anisotropy of magnetic susceptibility is a petrofabric tool used to estimate the alignment of minerals at the site-scale, the imbrication between the magnetic foliation and the emplacement surface being an indicator of flow direction. However, despite numerous studies examining the flow direction in pyroclastic deposits and lava flows, the effect of magnetic mineralogy and the domain state of ferromagnetic phases on the magnetic fabric remains poorly understood. This paper describes the magnetic mineralogy and its influence on the magnetic fabric of Plio-Pleistocene lava flows and ignimbrites of the Caviahue-Copahue Volcanic Complex in the Andean Southern Volcanic Zone, Argentina. Rock magnetism, anisotropy of magnetic susceptibility and anhysteretic remanent magnetization and petrographic observations were performed on 30 sites of the volcanic complex. Results revealed the extrusive and pyroclastic rocks present varied magnetic mineralogy, formed in different stages of the magmatic evolution. Magnetic mineralogy variations strongly affect the anisotropy of magnetic susceptibility data in volcanic rocks and associated ignimbrites, providing 'scattered' fabrics when late Tirich titanomagnetite phases dominate the fabric, and 'inverse' or 'intermediate' fabrics when single-domain grains are present. 'Normal' fabrics are typically found when early crystallized pure magnetite is present. Our results highlight the complexity in the interpretation of magnetic anisotropy data in volcanic rocks and ignimbrites.
\end{abstract}

Key words: AMS; AARM; Magnetic Mineralogy; Caviahue-Copahue Volcanic Complex.

\section{INTRODUCTION}

Volcanic environments, including the distribution of the caldera and associated volcanoes, has long been a focus of several studies (e.g. Geshi et al. 2002; Cole et al. 2005; Riel et al. 2015). The study of volcanism and, especially large collapsing caldera events, provide insights into the mantle thermal flux and tectonomagmatic process (Ort et al. 2013). The evolution of volcanic calderas usually involves the collapse of a volcanic edifice and the accumulation of extensive lava and ignimbrite deposits (Gudmundsson et al. 2016). The relatively short timescale of this process often results in explosive volcanism and the development of Pyroclastic Density Currents (PDCs), which can be used in the identification of volcanic centres, assisting the reconstruction of volcanic environments and their geologic evolution. Located in the Andean Southern Volcanic Zone, the Caviahue-Copahue Volcanic Complex (CCVC), Argentina, represents a natural laboratory to the study of volcano-caldera complexes, given its structural complexity (Folguera et al. 2016) and lithological diversity (Melnick et al. 2006).

Anisotropy of magnetic susceptibility (AMS) has been used as a petrofabric approach in a wide range of geological applications (e.g. Graham 1954; Hrouda 1982; MacDonald \& Ellwood 1987; Rochette et al. 1992; Kodama 1995; Borradaile \& Henry 1997; Martín-Hernández et al. 2004; Borradaile \& Jackson 2010). In particular, AMS is used to evaluate flow direction in lava and pyroclastic flow deposits especially in volcanic systems with restricted outcrops (e.g. Cañón-Tapia 2004) and undefined stratigraphic relationships, in order to determine vent location. In lava flows, the AMS results from the preferential crystallographic or shape preferred orientation at the final stage of the flux and by crystal shear during lava 
emplacement (Cañón-Tapia et al. 1996). However, several factors, such as viscosity and flux velocity control mineral alignment and distribution and, as a consequence, can directly influence the AMS signal. In ignimbrites, the AMS is strongly influenced by the transport, deposition and concentration of fragments. In the interior of PDCs, these fragments are preferably aligned along with the flux by interaction with other grains and the substrate, acquiring an imbrication that indicates the flow direction (Elston \& Smith 1970).

Several authors studied the control exerted by flow dynamics on the AMS signal of lavas and ignimbrites (e.g. Cañón-Tapia et al. 1995; Cañón-Tapia 2004; LaBerge et al. 2009; Ort et al. 2013). However, comparatively little attention has been given to the role of magnetic mineralogy on the magnetic fabrics (e.g. Khan 1962; Wing-Fatt \& Stacey 1966; Rochette et al. 1999). Recent studies have shown that in addition to macroscopic factors related to the flow of lava and pyroclastic material, the AMS fabrics also show strong dependence on microscopic factors, such as composition, mineral magnetic interactions and domain structure of the $\mathrm{Fe}-\mathrm{Ti}$ oxides, which most often control the AMS of volcanic rocks (Borradaile 1987; Cañón-Tapia 2004; Chadima et al. 2009; Cañón-Tapia \& Mendoza-Borunda 2014; Magee et al. 2016; Wiegand et al. 2017). For example, the 'SD effect', which is commonly associated to the inverse magnetic fabric of single-domain titanomagnetite grains (Stephenson et al. 1986; Potter \& Stephenson 1988), can be unveiled by correlating AMS data, magnetic mineralogy and measurements of the anisotropy of anhysteretic remanent magnetization (AARM). The rarity of observations of the 'SD-effect' may be caused by the fact that SD grains have a much smaller volume and thus contribute to the overall susceptibility (and its anisotropy) much less than MD grains. Also, correlation of AMS and AARM can indicate different carrier minerals, e.g. AMS may be dominated by MD magnetite while AARM by SD magnetite. In this paper, we present an AMS study including different volcanic units from CCVC. This work consists of an analysis of magnetic mineralogy control on the magnetic fabric and proposes some ways to reduce the ambiguity of interpretation on lava and pyroclastic flow directions. To attain this objective, we present the results of geology fieldwork, petrography and scanning electron microscopy observations, AMS and AARM, and a detailed examination of the magnetic mineralogy of the different volcanic units along with the volcanic complex. The CVCC shows a wide compositional range, from basalts to rhyolites and displays both explosive (ignimbrites) and effusive (lava flows) deposits, making the site an excellent environment to evaluate petrofabric studies from AMS data.

\section{GEOLOGICAL SETTING AND SAMPLING}

\subsection{Local geology and stratigraphy}

The Caviahue-Copahue Volcanic Complex (CCVC) is located in the Andean southern volcanic zone (SVZ: $33.3^{\circ} \mathrm{S}-46^{\circ} \mathrm{S}$ ) along the Chile-Argentina border (Fig. 1). It is positioned about $30 \mathrm{~km}$ from the current volcanic arc and, in these latitudes, volcanism is associated with the oblique subduction of the Nazca Plate under the South American Plate. Several studies suggest compositional variations for the evolution of the CCVC, from basaltic andesites to rhyolites, with characteristics of medium to high-K calc-alkaline and metaluminous series (Mazzoni \& Licitra 2000; Varekamp et al. 2006).
Stratigraphy of the CCVC is composed of nine volcanic units (Fig. 1b). The eruptive sequence begins with effusive and pyroclastic events under an extensional tectonic regime (Folguera et al. 2003), whose deposits are grouped in the Cola de Zorro Formation, also described in the literature as the Hualcupén Formation (Pesce 1989). This unit is characterized by sub-horizontal basalt and andesite lava flow deposits intercalated with non-welded ignimbrites of andesitic composition (Fig. 2a) which covers a wide segment of the studied area (Fig. 1b).

A volcano-tectonic depression of approximately $20 \times 15 \mathrm{~km}$ and $0.5 \mathrm{~km}$ deep (Fig. 1b) was developed during the Upper Pleistocene Pliocene (ca. 2 Ma; Linares et al. 1999; Folguera \& Ramos 2000) and was named Caviahue Depression (Groeber 1925) or Caldera del Agrio (Pesce 1989). Based on the structural analysis and previous works (e.g. Folguera \& Ramos 2000; Melnick et al. 2006), Sruoga \& Consoli (2011) recommended the abandonment of the term caldera, advocating for a structural origin for the Caviahue Depression. In contrast, other works support the volcanic origin based on the ignimbrite presence both inside and outside of the Caviahue Depression (e.g. Pesce 1989; Mazzoni \& Licitra 2000), favouring, therefore, the caldera hypothesis. In this depression, two main units were recognized: Las Mellizas Formation and Trolope Lavas (Pesce 1989; Melnick et al. 2006).

The Las Mellizas Formation is characterized by two effusive events (Lower and Upper Lavas) intercalated by an explosive one (Las Mellizas Ignimbrites). The Lower Lavas unit is represented by remarkably columnar-jointed lavas of basaltic to andesitic composition (Fig. 2b) interbedded with some sedimentary deposits (Melnick et al. 2006). Las Mellizas Ignimbrites are characterized by andesitic to dacitic compositions presenting a widespread distribution inside the Caviahue Depression (Mazzoni \& Licitra 2000). This pyroclastic sequence is composed of high-grade ignimbrites with vertical lithofacies variation, including basal vitrophyres with gradations from lithic clast-bearing deposits to rheomorphic units with eutaxitic (Fig. 2c) and parataxitic structures (Fig. 2d) (Mazzoni \& Licitra 2000). The Upper Lavas sequence (Fig. 2e) overlie the ignimbrites and is partially covered by flows from the Copahue Volcano. This unit is essentially composed of andesitic lava flows with sub-horizontal foliation and homogenous thicknesses and textures (Melnick et al. 2006). Located northeast of the studied area and filling the northeastern entrance canyon of the Caviahue Depression, the Trolope Lavas form a $200 \mathrm{~m}$ thick succession of homogeneous trachyandesitic lava flows and breccias (Melnick et al. 2006).

Almost $15 \mathrm{~km}$ outside the Caviahue Depression border, a thin cover of dense pyroclastic current deposit forms the Riscos Bayos Formation. This irregularly distributed unit has been often interpreted as the outflow ignimbrites associated with the putative caldera collapse (Mazzoni \& Licitra 2000). This deposit is composed of non-welded ignimbrites (Fig. 2f) with andesitic (lower and intermediate units) and rhyolitic (upper unit) compositions with observable internal structures marked by the concentration of lithics in the base and of pumices in the top of the deposits (Mazzoni \& Licitra 2000).

The Copahue Volcano, an active volcano of basaltic andesitic composition, occupies the southwestern corner of the Caviahue Depression. Copahue evolution is marked by successive effusive and pyroclastic (subordinate) events from a central conduit and related lateral fissures, with the units divided into pre-, sin- and postglacial phases (Melnick et al. 2006; Sruoga P 2011). The historical deposits of the eruptive cycles of 1992, 1995, 2000 and 2012 mainly involved ash, bombs and lithic fragments, besides rare lahars (Melnick et al. 2006). The Pucón Mahuida and Cerro Bayo domes present rhyolitic 


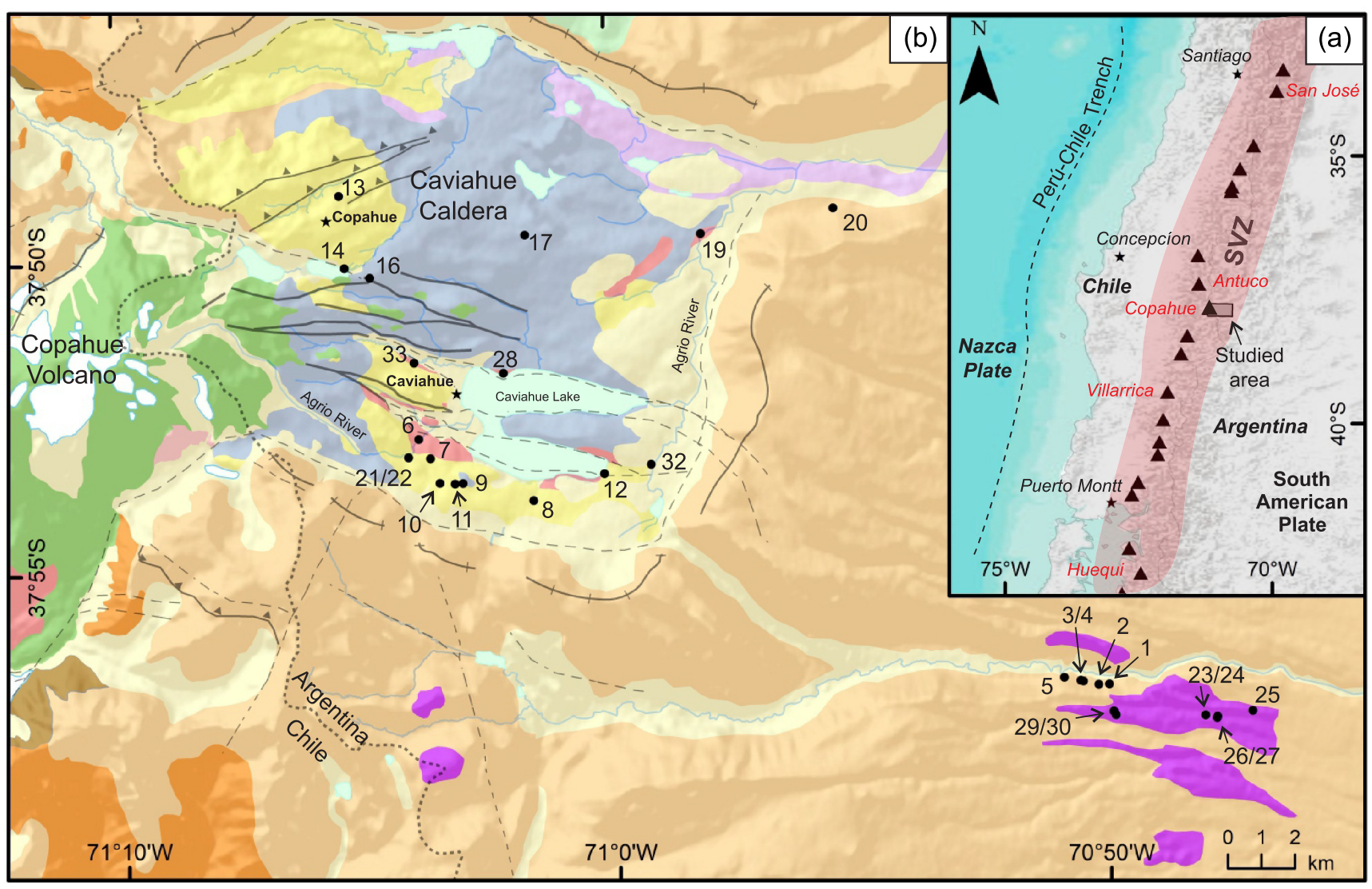

\section{Geologic units and legend:}

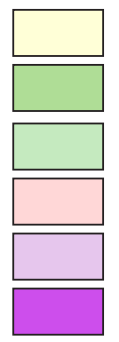

Sedimentary deposits

Copahue Volcano stages

Cerro Bayo dome

Pucón Mahuida dome

Trolope lavas

Riscos Bayos ignimbrite

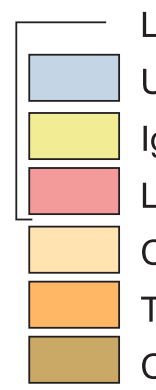

Las Mellizas volcanic sequence

Upper lavas

Ignimbrites

Lower lavas

Cola de Zorro Formation

Trapa - Trapa Formation

Cura-Mallin Formation

$\bigcirc$ Glacial

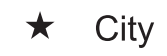

River

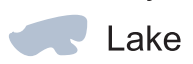

- Sampling sites

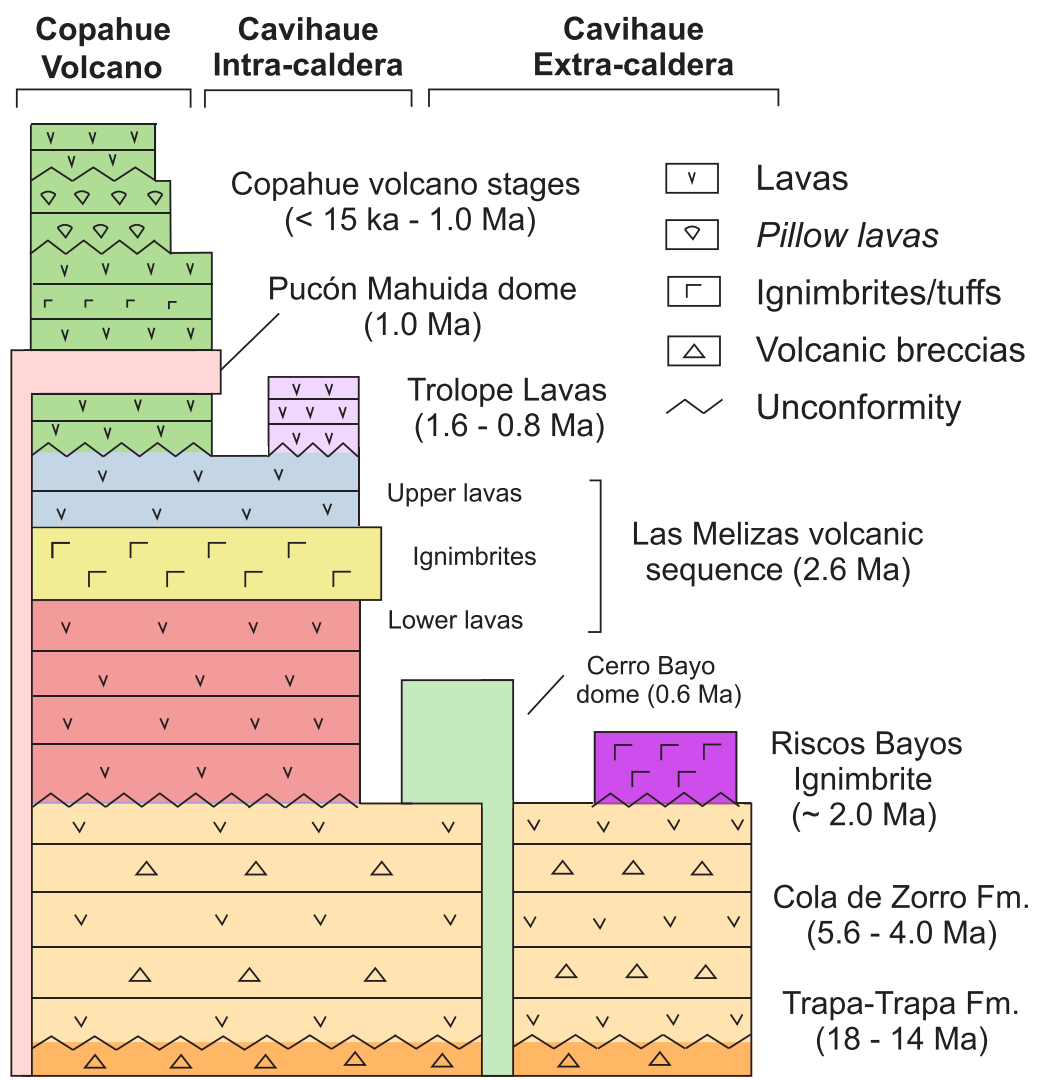

Figure 1. (a) Location map and main regional structures of the Andean intra-arc zone with a detail of southern volcanic zone (SVZ); (b) Geological map and stratigraphic chart for CCVC (Modified from Melnick et al. 2006), where the black dots represent all 30 sampling sites. 

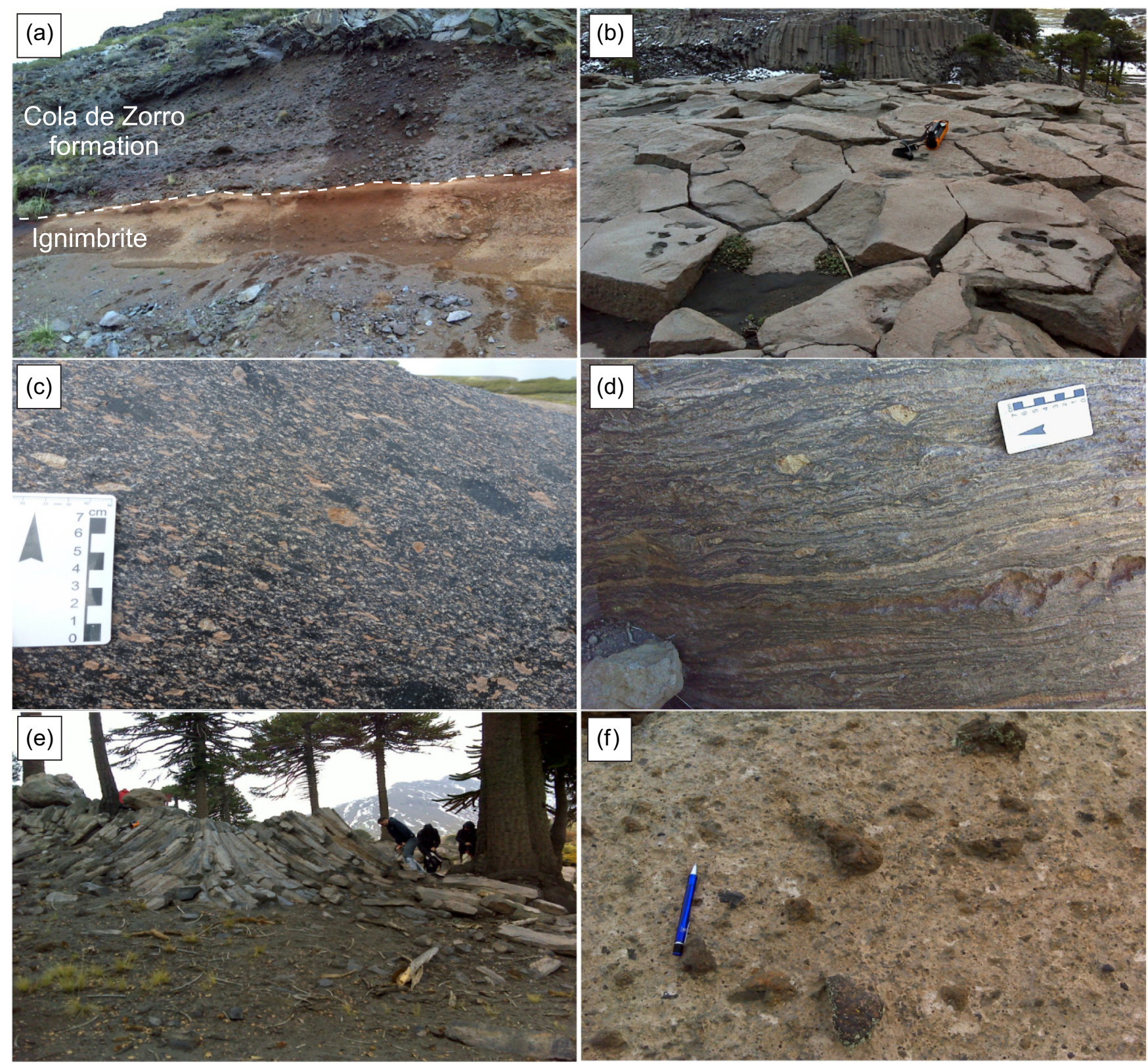

Figure 2. Field aspects of CCVC units. (a) scoriaceous basal portion of the Cola de Zorro basaltic lava flows; (b) subvertical joints in the lower lavas of the Las Mellizas Volcanic Sequence; (c) welded ignimbrite of the Las Mellizas Volcanic Sequence; (d) rheomorphic ignimbrite of the Las Mellizas Volcanic sequence showing parataxitic texture and lithic fragments; (e) geometry and subvertical joints in the upper lavas of the Las Mellizas Volcanic Sequence; (f) no welded andesitic ignimbrite of the Riscos Bayos unit.

to dacitic compositions and are composed of lava flows and subvolcanic bodies, with the first one located on the southeastern slope of the Copahue volcano and the second located in the northern edge of the Caviahue (Folguera \& Ramos 2000; Melnick et al. 2006).

$\mathrm{K}$-Ar ages are available for all the studied units (Muñoz \& Stern 1988; Linares et al. 1999), although some authors point out possible errors in the analyses (e.g. Melnick et al. 2006; Folguera et al. 2016) The volcanic stage of the Cola de Zorro Formation is Early Pliocene $(5.67 \pm 0.14 \mathrm{Ma}$ to $4.00 \pm 0.10 \mathrm{Ma})$ according to available $\mathrm{K}-\mathrm{Ar}$ ages obtained from the inner wall of the Caviahue Depression. A Late Pliocene age for Las Mellizas sequence is given by three $\mathrm{K}-\mathrm{Ar}$ ages (2.68 $\pm 0.14 \mathrm{Ma}$ to $2.60 \pm 0.10 \mathrm{Ma}$ ) (Linares et al. 1999). The age of Riscos Bayos ignimbrite is less well constrained, with contrasting K-Ar results obtained by Linares et al. (1999) (2.05 \pm
$0.10 \mathrm{Ma})$ and Muñoz \& Stern (1988) (1.1 $\pm 0.5 \mathrm{Ma})$. A Pleistocene age for the Trolope Lavas is provided by four K-Ar ages between $1.63 \pm 0.10$ and $0.82 \pm 0.16$ Ma with the following development of the Copahue volcano beginning about 1.2 Ma (Linares et al. 1999). $\mathrm{K}$-Ar ages of 1.23 to $0.6 \mathrm{Ma}$ were obtained from the Pucón Mahuida and Cerro Bayo domes (Muñoz \& Stern 1988; Linares et al. 1999).

\subsection{Sampling}

In the fieldwork, a total of 239 oriented cylindrical cores were collected from 30 sites (Fig. 1b) using a portable, gasolinepowered drill. All samples were oriented using a magnetic compass, and when possible sun compass. The magnetic declination was 
systematically $03^{\circ} \mathrm{W}$. Sampled sites with location are reported in Table 1. Sites COP01-COP05 and COP20 were collected from Cola de Zorro Formation, and correspond to sub-horizontal lava flow at the base of the stratigraphy. Sites COP23-COP27 and COP29COP30 were collected on the Riscos Bayos ignimbrite (non-welded ignimbrites). From Las Mellizas Volcanic Sequence, we collected from Lower lavas (sites COP06, COP19, COP28 and COP33), welded ignimbrites (sites COP07-COP08, COP11-COP14, COP22 and COP32) and Upper lavas (sites COP09-COP10, COP16-COP17 and COP21). At the laboratory, all cylindrical samples were cut into specimens of $2.5 \mathrm{~cm}$ diameter and $2.2 \mathrm{~cm}$ height for AMS and AARM measurements, totalizing 430 specimens. From each site, we also separated some material for magnetic mineralogy experiments, petrography and scanning electron microscopy analyses.

\section{METHODS}

\subsection{Petrography and scanning electron microscopy (SEM) observations}

We performed petrographic, directional and scanning electron microscope (SEM) analysis in six representative samples of the studied sites. Petrographic analysis was performed at the Laboratório de Paleomagnetismo e Magnetismo de Rochas, Universidade de São Paulo (USPMag), using a petrographic transmitted/reflected light microscope (Olympus BX41). In addition to conventional petrographic analyses, we used ImageJ (Schindelin et al. 2012) to perform supervised directional analyses of the major axis of both silicate and oxide crystals. SEM observations were carried out at the Laboratório de Caracterização Tecnológica of the Departamento de Engenharia de Petróleo, Universidade de São Paulo (LCT/USP). Quantitative observations of SEM were performed on six carboncoated samples using a Stereoscan S440 (LEO) SEM with resolution about $10 \mathrm{~nm}$. Compositional maps were performed using a Quanta 600 FEG SEM (FEI Company). Both microscopes were operated at $20 \mathrm{kV}$, with a magnification of 7000-7500 X. Backscattered Energy Dispersive Spectra (EDS) images (ESPRIT software) and chemical maps (EDS X-ray maps) of major elements abundances were acquired on representative parts of each sample. Note that SEM observations were performed on bulk rock samples.

\subsection{Magnetic mineralogy characterization}

To complement the interpretation of magnetic fabric, the magnetic properties and proportions of grain size were analysed. Magnetic mineralogy was investigated through temperature-dependent lowfield magnetic susceptibility curves ( $\chi$-T diagrams), isothermal remanent magnetization (IRM) acquisition curves, hysteresis loops and first-order reversal curves (FORC) diagrams.

Temperature-dependent low-field magnetic susceptibility measurements $(\chi-T)$ were performed in one representative sample for each sampling site. Samples were manually crushed in an agate mortar and the magnetic susceptibility of the powder was measured during continuous heating and cooling curves between room temperature and $\sim 600{ }^{\circ} \mathrm{C}$ using a Kappabridge KLY4 coupled with a CS3 furnace (Agico Ltd.). The degree of reversibility of heating and cooling cycles reflect phase transformations during the thermomagnetic experiment. It was estimated using the alteration indexes defined in Hrouda (2003) that estimate the maximum difference in susceptibility between curves $\left(A_{\max }\right)$ and the difference in susceptibility at $40^{\circ} \mathrm{C}\left(A_{40}\right)$. Curves were considered reversible when both Amax and $A_{40}$ values were below 20 (absolute value). The determination of phase transformations of magnetic minerals and the reversibility of the heating-cooling cycles provide information on the nature of the original magnetic grains and the stability of the magnetic carriers upon temperature (e.g. Hrouda 1994, 2003). Transition temperatures of magnetic minerals (Curie temperatures, Tc) were obtained by the second-derivative of the heating curve (Tauxe 1998).

Hysteresis loops and isothermal remanent magnetization (IRM) acquisition curves were measured at room temperature in small rock chips cut from one specimen per site. Measurements were performed by applying fields of up to $1 \mathrm{~T}$ using a Princeton Measurements Corporation Micromag vibrating sample magnetometer (VSM). The saturation magnetization (Ms), saturation remanent magnetization (Mrs), coercivity (Bc) and coercivity of remanence (Bcr) are all determined from hysteresis loops and backfield measurements. The ratios of $\mathrm{Mrs} / \mathrm{Ms}$ and $\mathrm{Bcr} / \mathrm{Bc}$ reflect relative proportions of the single domain (SD), multidomain (MD) and pseudosingle domain (PSD) structures of the magnetic minerals (e.g. Day et al. 1977; Dunlop \& Özdemir 1997; Dunlop 2002).

These standard hysteresis parameters, however, provide only a measure of the bulk magnetic properties and therefore are not suitable for discriminating the different magnetic components contributing to the magnetization in samples with mixed magnetic assemblage, e.g. samples plotting in the PSD region in the Day et al. (1977) diagram could be mixtures of SD and MD grains rather than PSD grains and this distinction cannot be made from a Day plot alone. Given the complex magnetic mineralogy in our samples, we used first-order reversals curves (FORCs) to identify and discriminate the different magnetic mineral assemblages (Roberts et al. 2014). In addition, FORC diagrams also indicate the presence of magnetostatic interactions among magnetic grains (Roberts et al. 2000, 2014). FORC measurements were performed at room temperature after 300 reversal curves with an averaging time of $200 \mathrm{~ms}$. FORC diagrams were calculated using the FORCinel software package (Harrison \& Feinberg 2008) with a smoothing factor of 4 for all samples.

\subsection{Anisotropies of magnetic susceptibility (AMS) and anhysteretic remanent magnetization (AARM)}

The anisotropy of low-field magnetic susceptibility (AMS) was used to infer the petrofabric of our rock collection. AMS is a superposition of dia-, paramagnetic and ferromagnetic minerals in the rock and depends on their intrinsic anisotropy and spatial distribution within a rock sample (Tarling \& Hrouda 1993). AMS measurements consist of the acquisition of magnetic susceptibility measurements in different directions to resolve the magnetic susceptibility $(\mathrm{K})$ tensor. In practice, the magnetic susceptibility tensor is represented by an ellipsoid of magnetic susceptibility, defined by the length and orientation of its three principal axes $K_{1}, K_{2}$ and $K_{3}\left(K_{1} \geq K_{2} \geq K_{3}\right)$. The mean magnetic susceptibility $\left(K_{\mathrm{m}}\right)$ is the arithmetic mean of $K_{1}, K_{2}$ and $K_{3}$. Several parameters have been proposed to express the shape and degree of anisotropy of the susceptibility ellipsoid. The magnetic lineation is defined as the maximum susceptibility axis $\left(K_{1}\right)$ and the magnetic foliation is defined as the plane containing maximum and intermediate axes $\left(K_{1}\right.$ and $\left.K_{2}\right)$ and perpendicular to the minimum axis $\left(K_{3}\right)$. The magnitude of these parameters can be computed as a ratio between the main axes: magnetic lineation $\left(L=K_{1} / K_{2}\right)$ and magnetic foliation $\left(F=K_{2} / K_{3}\right)$. The shape of the anisotropy tensors is usually 
Table 1. AMS data from the studied sites. $N=$ number of specimens measured; $K \mathrm{~m}=$ mean susceptibility; $L=$ lineation; $F=$ foliation; $P^{\prime}=$ corrected degree of anisotropy; $T=$ Jelineck's parameter (Jelinek 1981 ); $D=$ declination; $I=$ inclination; $E_{1-2}, E_{2-3}, E_{1-3}$ : semi-angles of the 95 per cent confidence ellipses around the principal susceptibility axes, values in parentheses are standard deviation. * sites with AARM measurements. Tc is the estimated Curie temperature.

\begin{tabular}{|c|c|c|c|c|c|c|c|c|c|c|c|c|c|c|}
\hline \multirow[t]{2}{*}{ Site ID } & \multicolumn{2}{|c|}{ UTM } & \multirow[t]{2}{*}{$n$} & \multirow{2}{*}{$\begin{array}{c}K_{m} \\
\left(10^{-2} \mathrm{SI}\right)\end{array}$} & \multirow[t]{2}{*}{$L$} & \multirow[t]{2}{*}{$F$} & \multirow[t]{2}{*}{$P^{\prime}$} & \multirow[t]{2}{*}{$T$} & \multirow{2}{*}{$\begin{array}{l}K_{1} \\
\mathrm{D}, \mathrm{I}\end{array}$} & \multirow{2}{*}{$\begin{array}{l}K_{3} \\
\mathrm{D}, \mathrm{I}\end{array}$} & \multirow{2}{*}{$\begin{array}{c}E_{1-2} \\
\left({ }^{\circ}\right)\end{array}$} & \multirow{2}{*}{$\begin{array}{c}E_{2-3} \\
\left({ }^{\circ}\right)\end{array}$} & \multirow{2}{*}{$\begin{array}{c}E_{1-3} \\
\left({ }^{\circ}\right)\end{array}$} & \multirow[t]{2}{*}{$\operatorname{Tc}\left({ }^{\circ} \mathrm{C}\right)$} \\
\hline & $\mathrm{E}$ & $\mathrm{N}$ & & & & & & & & & & & & \\
\hline \multicolumn{15}{|c|}{ Las Mellizas - Upper Lavas } \\
\hline COP09* & 319698 & 5803947 & 21 & $1.18(0.10)$ & $1.004(0.001)$ & $1.006(0.001)$ & $1.010(0.002)$ & $0.170(0.161)$ & 234.80 & 93.8 & 9 & 6 & 6 & 533 \\
\hline COP10 & 319005 & 5803952 & 16 & $2.37(0.22)$ & $1.009(0.002)$ & $1.006(0.003)$ & $1.016(0.004)$ & $-0.193(0.147)$ & 7.12 & 220.76 & 11 & 8 & 10 & 575 \\
\hline COP16* & 316909 & 5810063 & 12 & $1.10(0.18)$ & $1.001(0.003)$ & $1.003(0.002)$ & $1.005(0.004)$ & $0.410(0.326)$ & 185.27 & 309.47 & 50 & 29 & 30 & 178 \\
\hline COP17 & 316909 & 5810063 & 20 & $1.48(0.12)$ & $1.004(0.001)$ & $1.007(0.002)$ & $1.011(0.002)$ & $0.304(0.202)$ & 259.21 & 68.69 & 7 & 4 & 5 & 587 \\
\hline COP21 & 321530 & 5811343 & 7 & $1.12(0.10)$ & $1.008(0.002)$ & $1.010(0.001)$ & $1.018(0.002)$ & $0.127(0.108)$ & 101.82 & 240.6 & 13 & 6 & 8 & 400 \\
\hline \multicolumn{15}{|c|}{ Las Mellizas - Ignimbrites } \\
\hline $\mathrm{COP} 07^{*}$ & 318723 & 5804683 & 12 & $1.18(0.12)$ & $1.002(0.001)$ & $1.009(0.004)$ & $1.012(0.004)$ & $0.598(0.305)$ & 247.18 & 62.72 & 22 & 4 & 6 & 565 \\
\hline COP08* & 321804 & 5803438 & 16 & $1.32(0.14)$ & $1.001(0.001)$ & $1.004(0.001)$ & $1.005(0.001)$ & $0.739(0.250)$ & 112.5 & 223.77 & 34 & 6 & 6 & 564 \\
\hline COP $11^{*}$ & 319460 & 5803932 & 15 & $1.20(0.15)$ & $1.005(0.002)$ & $1.004(0.003)$ & $1.009(0.002)$ & $-0.111(0.452)$ & 179.36 & 341.52 & 21 & 12 & 6 & 562 \\
\hline $\mathrm{COP} 12^{*}$ & 323911 & 5804243 & 17 & $2.67(0.33)$ & $1.001(0.001)$ & $1.009(0.002)$ & $1.011(0.002)$ & $0.840(0.224)$ & 119.3 & 17.74 & 39 & 7 & 7 & 537 \\
\hline COP13* & 315966 & 5812495 & 14 & $1.36(0.17)$ & $1.001(0.002)$ & $1.010(0.004)$ & $1.012(0.004)$ & $0.822(0.293)$ & 184.21 & 22.68 & 56 & 7 & 12 & 444 \\
\hline COP14* & 316149 & 5810346 & 7 & $1.52(0.17)$ & $1.005(0.002)$ & $1.011(0.002)$ & $1.016(0.003)$ & $0.372(0.138)$ & 236.59 & 327.1 & 18 & 6 & 13 & 430 \\
\hline COP $22^{*}$ & 318068 & 5804710 & 15 & $1.49(0.14)$ & $1.002(0.001)$ & $1.006(0.001)$ & $1.009(0.002)$ & $0.500(0.227)$ & 288.6 & 174.77 & 5 & 19 & 6 & 571 \\
\hline COP32* & 325305 & 5804519 & 19 & $1.50(0.07)$ & $1.001(0.001)$ & $1.014(0.003)$ & $1.017(0.003)$ & $0.839(0.137)$ & 329.14 & 94.67 & 38 & 5 & 6 & 568 \\
\hline \multicolumn{15}{|c|}{ Las Mellizas - Lower Lavas } \\
\hline COP06 & 318396 & 5805231 & 13 & $1.44(0.12)$ & $1.001(0.004)$ & $1.003(0.001)$ & $1.004(0.004)$ & $0.333(0.369)$ & 82.13 & 177.21 & 53 & 15 & 15 & 158 \\
\hline COP19 & 326776 & 5811393 & 10 & $1.58(0.05)$ & $1.005(0.003)$ & $1.002(0.006)$ & $1.007(0.007)$ & $-0.433(0.324)$ & 64.45 & 313.19 & 51 & 27 & 44 & 189 \\
\hline COP28* & 320900 & 5807231 & 23 & $2.57(0.22)$ & $1.017(0.003)$ & $1.004(0.002)$ & $1.023(0.003)$ & $-0.609(0.154)$ & 249.3 & 152.65 & 17 & 7 & 15 & 230 \\
\hline COP33 & 318230 & 5807530 & 24 & $1.24(0.09)$ & $1.021(0.003)$ & $1.005(0.003)$ & $1.028(0.003)$ & $-0.640(0.188)$ & 276.11 & 124.78 & 9 & 4 & 9 & 191 \\
\hline \multicolumn{15}{|c|}{ Riscos Bayos - Ignimbrites } \\
\hline COP23* & 341855 & 5797063 & 18 & $0.70(0.04)$ & $1.003(0.002)$ & $1.010(0.006)$ & $1.013(0.007)$ & $0.581(0.148)$ & 245.3 & 145.75 & 23 & 7 & 7 & 597 \\
\hline COP24 & 341855 & 5797063 & 8 & $0.35(0.01)$ & $1.004(0.002)$ & $1.002(0.003)$ & $1.006(0.003)$ & $-0.305(0.412)$ & 330.61 & 89.15 & 35 & 24 & 32 & 585 \\
\hline $\mathrm{COP} 25$ & 343248 & 5797194 & 10 & $0.33(0.05)$ & $1.009(0.005)$ & $1.018(0.005)$ & $1.027(0.006)$ & $0.353(0.280)$ & 301.18 & 98.71 & 21 & 9 & 11 & 432 \\
\hline COP26 & 342200 & 5797020 & 13 & $0.25(0.07)$ & $1.002(0.003)$ & $1.003(0.004)$ & $1.005(0.005)$ & $0.302(0.459)$ & 312.49 & 122.41 & 58 & 27 & 27 & 280 \\
\hline COP27 & 342191 & 5796983 & 8 & $0.65(0.32)$ & $1.004(0.005)$ & $1.002(0.005)$ & $1.006(0.009)$ & $-0.191(0.506)$ & 298.33 & 95.54 & 43 & 25 & 34 & 584 \\
\hline $\mathrm{COP} 29^{*}$ & 339110 & 5797170 & 12 & $0.42(0.02)$ & $1.009(0.003)$ & $1.010(0.002)$ & $1.019(0.003)$ & $0.065(0.183)$ & 34.32 & 123.58 & 11 & 7 & 10 & 584 \\
\hline $\mathrm{COP} 30$ & 397107 & 5797178 & 14 & $0.34(0.06)$ & $1.003(0.001)$ & $1.004(0.002)$ & $1.007(0.002)$ & $0.164(0.316)$ & 311.22 & 146.68 & 16 & 9 & 12 & 530 \\
\hline \multicolumn{15}{|c|}{ Cola de Zorro - Lavas } \\
\hline COP01 & 338971 & 5797984 & 19 & $1.79(0.13)$ & $1.000(0.001)$ & $1.018(0.002)$ & $1.021(0.002)$ & $0.971(0.095)$ & 128.10 & 21.59 & 79 & 5 & 10 & 585 \\
\hline $\mathrm{COP} 02^{*}$ & 338663 & 5797976 & 12 & $1.80(0.11)$ & $1.016(0.007)$ & $1.009(0.004)$ & $1.026(0.009)$ & $-0.261(0.183)$ & 77.28 & 202.48 & 9 & 4 & 7 & 574 \\
\hline COP03* & 338201 & 5798069 & 15 & $1.25(0.14)$ & $1.010(0.002)$ & $1.014(0.004)$ & $1.025(0.004)$ & $0.169(0.167)$ & 212.5 & 4.85 & 15 & 9 & 12 & 586 \\
\hline COP04* & 338158 & 5798078 & 12 & $1.03(0.14)$ & $1.002(0.003)$ & $1.002(0.003)$ & $1.004(0.003)$ & $-0.157(0.398)$ & 359.21 & 96.16 & 49 & 36 & 47 & 190 \\
\hline $\mathrm{COP} 05$ & 337627 & 5798182 & 17 & $1.99(0.31)$ & $1.012(0.007)$ & $1.002(0.005)$ & $1.015(0.005)$ & $-0.742(0.462)$ & 248.14 & 60.76 & 44 & 14 & 40 & 313 \\
\hline COP20 & 330723 & 5812160 & 11 & $3.52(0.53)$ & $1.017(0.004)$ & $1.018(0.004)$ & $1.035(0.005)$ & $0.035(0.184)$ & 268.12 & 160.55 & 9 & 7 & 9 & 587 \\
\hline
\end{tabular}

evaluated through the $T$ parameter $\left(T=2 \cdot \ln \left(K_{2} / K_{3}\right) / \ln \left(K_{1} / K_{3}\right)-\right.$ $1)$, which is used to distinguish among prolate $(T<0)$, oblate $(T>0)$ or triaxial ellipsoids $(T=0)$ (Jelinek 1981). The degree of anisotropy is given by $P=K_{1} / K_{3}$ or, in its corrected form, by $P^{\prime}=\exp \left[\sqrt{2\left(\left(\eta_{1}-\eta_{m}\right)^{2}+\left(\eta_{2}-\eta_{m}\right)^{2}+\left(\eta_{3}-\eta_{m}\right)^{2}\right)}\right]$ (Jelinek 1981), where $\eta_{i}$ is the natural logarithm of $K_{i}$. AMS measurements were performed with an automatic Kappabridge MFK1-A apparatus (Agico Ltd.), using the rotation mode and operating in a low alternating field $\left(300 \mathrm{~A} \mathrm{~m}^{-1}\right)$ at $976 \mathrm{~Hz}$. Measurements were performed on all 30 sampled sites (430 specimens), comprising 16 sites of lava flows and 14 of both welded and non-welded ignimbrites. All the stereonets presented in this study are in the bedding coordinate system (bedding being rotated to the horizontal).

The AARM was determined to isolate the contribution of remanence-carrying minerals from that of the paramagnetic and diamagnetic matrix as well as to exclude the presence of inverse fabrics (Jackson 1991). The anhysteretic remanent magnetization $(A R M)$ is acquired when a ferromagnetic grain is subjected simultaneously to an alternating magnetic field (AF) and a small bias direct field. Similarly to the AMS, for low bias fields the AARM can be described by an ellipsoid of anhysteretic remanence $\left(M_{A}\right)$, with three orthogonal axis $M_{1}, M_{2}$ and $M_{3}\left(M_{1} \geq M_{2} \geq M_{3}\right)$ (Jackson 1991). Schemes with 6,12 and 15 positions were tested and the 15 positions scheme was the only one that resolved for all samples the AARM tensor with confidence following the F-test of Jelínek (1977). Before AARM analysis, samples were AF demagnetized in $100 \mathrm{mT}$ to establish the base level. ARM was acquired with an AF peak field of $100 \mathrm{mT}$ and a bias field of 0.50
$\mathrm{mT}$ to cover most of the grain-size populations. ARM acquisitions were performed with an LDA3-AMU1 (AGICO, Inc) and remanence measurements after each inducing step were performed with a JR6A magnetometer (sensitivity of less than $100 \mathrm{~A} \mathrm{~m}^{-1}$ ) (AGICO, Inc). AARM was measured on samples from 16 sites (Table 1).

\section{RESULTS}

\subsection{Petrography and SEM observations}

Overall, petrographic analysis shows large silicate crystals comprising essentially plagioclase with different sizes involved by a matrix with different degrees of crystallinity and textures (Fig. 3). Site COP01 (lava flow from Cola de Zorro Fm.; Figs 2a and 3a) presents a preferential alignment of plagioclase crystals, both of phenocrysts and of smaller crystals in the matrix (trachytic texture - S $=200^{\circ} / 05^{\circ} \mathrm{NW}$ ). Site COP05 (also a lava flow from Cola de Zorro Fm.; Fig. 3b) shows plagioclase phenocrysts roughly oriented within a fine matrix $\left(\mathrm{S}_{\circ}=200^{\circ} / 04^{\circ} \mathrm{NW}\right)$. Site COP33 (Las Mellizas Fm., Lower Lavas; Fig. 3c) exhibit slightly oriented phenocrysts of plagioclase and olivine involved by a glassy matrix $\left(\mathrm{S} \circ=030^{\circ} / 03^{\circ} \mathrm{SE}\right.$ ). Site COP09 (Las Mellizas Fm., Upper Lavas; Fig. 3d) presents oriented plagioclase phenocrysts and a fine matrix mainly composed of olivine, pyroxene, plagioclase and glass. All lava samples contain plagioclase with fine to coarse crystal reabsorption (sieve texture) suggesting rapid decompression during the magmatic events. The crystal alignment observed in the samples 

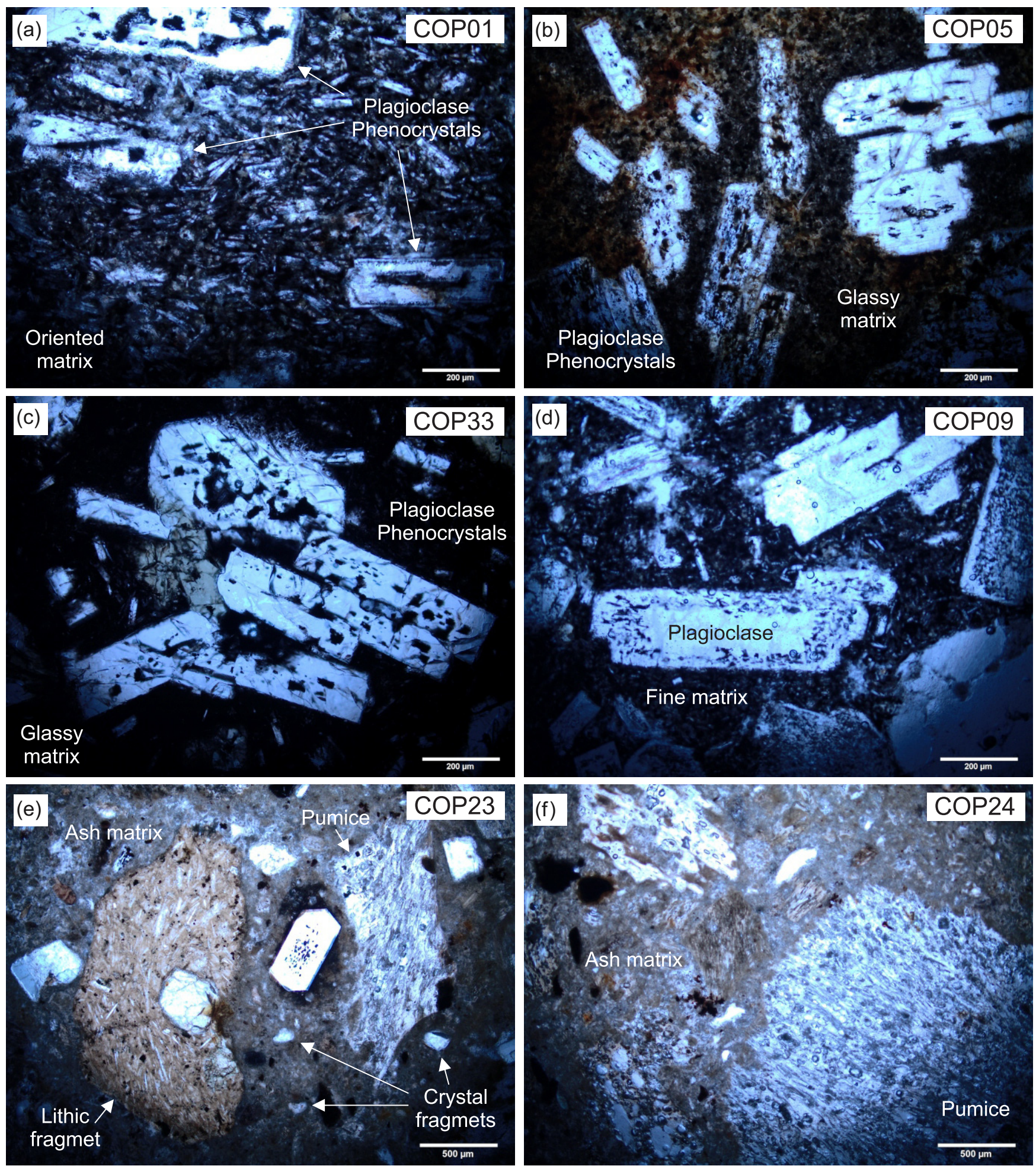

Figure 3. Photographs of thin sections of some sampling sites. (a, b) Cola de Zorro Fm. lava flows with trachytic texture showing clear matrix and plagioclase crystals orientation. (c) Las Mellizas Fm. Lower Lavas showing slightly oriented plagioclase phenocrystals involved by glassy matrix. (d) Las Mellizas Fm. Upper Lavas sample displaying oriented plagioclase phenocrystals and fine matrix. (e, f) Riscos Bayos Ignimbrites samples with non-welded pumice, lithics and crystal fragments involved by a fine ash matrix.

evidences the effective mechanical orientation of the silicate fabric inside the lava flows, which was observed and measured in the field. Sites COP23 and COP24 (Riscos Bayos ignimbrite; Figs 3e and f) present lithic and crystal fragments of pyroxene surrounded by a fine ash matrix and non-welded pumice. These samples also display a mean orientation defined by pumices porosity elongation and the imbrication of crystals and lithic fragments that were measured in the field $\left(\mathrm{S} \circ=020^{\circ} / 05^{\circ} \mathrm{SE}\right)$. 
Considering that most of our samples present plagioclase crystals as an important mineral phase, we used the major axis of these crystals to determine the orientation of the silicate fabrics in the studied samples, as proposed by Archanjo \& Launeau (2004) and Bascou et al. (2005). Due to the abundance of pumice and crystal fragments in the ignimbrites, we used these elements to define the silicate fabrics of these rocks. Rose diagrams based on the directional analysis performed using ImageJ suggest an effective orientation of both silicate and magnetite crystals (Fig. 4), with variable degrees of scattering. In special, Riscos Bayos Ignimbrites samples display a minor amount of magnetite crystals (Fig. 4; COP23 and COP24), resulting in a less defined magnetic visual orientation.

SEM observations show a wide variation of Fe-Ti oxide constituents, from pure magnetite to titanomagnetite crystals (Ti-mag) with variable amounts of Ti (from 0.14 to 51.37 per cent), as revealed by composition mapping of the selected samples (Fig. 5). In plagioclase and pyroxenes (large grain; Fig. 5), some Ti-magnetite (Ti-mag) crystals seems to have exsolved from the host mineral. This exsolved Ti-mag may carry remanence with a distinct orientation, depending upon its position along the edge of the lattice of the host mineral, which can ultimately influence or dominate the AMS signal (Biedermann et al. 2013). Samples also display wide variations concerning the crystal sizes, their spatial distribution, and shape, as presented by BSE images shown in Fig. 5. Site COP01 (Cola de Zorro Fm.) presents a uniform Ti-mag population with crystal sizes ranging from 10 to $50 \mu \mathrm{m}$ and low-Ti content (Fig. 5a), while site COP05 (Fig. 5b), from the same geological unit, exhibits a bimodal distribution of Ti-mag, one marked by abundant small crystals $(\sim 20 \mu \mathrm{m})$ and another characterized by larger, more scarce, rounded crystals $(\sim 300 \mu \mathrm{m})$, also with low-Ti content. Site COP33 (Las Mellizas Fm. - Lower Lavas) also displays two populations of Ti-mag with distinct crystal sizes $(\sim 20$ and $\sim 100 \mu \mathrm{m})$, both marked by idiomorphic crystals with straight and well-defined borders (Fig. 5c). Also from Las Mellizas Fm., site COP09 (Upper Lavas) shows a single low-Ti fine-grained $(\sim 10 \mu \mathrm{m})$ Ti-mag population well distributed throughout the entire fabric (Fig. 5d). In this site, we also observe a considerable amount of iron-oxides crystals smaller than $\sim 2 \mu \mathrm{m}$. Sites COP23 and COP24 (Riscos Bayos Fm.) display lower concentrations of Ti-mag and both are marked by idiomorphic crystals ranging from 40 to $200 \mu \mathrm{m}$ and presenting low-Ti content, although some high-Ti crystals may be visible in site COP23 (Figs 5e and f).

\subsection{Magnetic mineralogy}

Representative thermomagnetic curves are presented in Fig. 6. Estimated Curie temperatures (Table 1) suggest that the main magnetic mineral present in the rocks is titanomagnetite with variable $\mathrm{Ti}$ content from pure magnetite ( 0 per cent Ti) to Ti-rich titanomagnetite (40 per cent) (Dunlop \& Özdemir 1997). The reversibility of heating-cooling cycles depends mainly on the lithology and stratigraphic unit. Samples from Cola de Zorro Fm. show reversible curves during heating-cooling cycles (Figs 6a-c) and magnetic susceptibility with a high-temperature transition at $580-590{ }^{\circ} \mathrm{C}$, suggesting the presence of magnetite or Ti-mag with low Ti content. From Riscos Bayos Fm., samples also show high Tc around 580-600 ${ }^{\circ} \mathrm{C}$ (Figs 6 o, p, r and s) related to magnetite, however, they commonly present irreversible behaviour and in some cases, a Hopkinson peak in the heating curve (e.g. COP30). From Las Mellizas Lower Lavas, curves are not reversible and samples have the lowest Tc around $200^{\circ} \mathrm{C}$ (Figs 6e and $\mathrm{m}$ ) indicating Ti-mag with high Ti content. Welded ignimbrites from Las Mellizas present the same behaviour as that described for Riscos Bayos (Figs 6f, g, i, j and $t$ ). The Upper Lavas exhibit irreversible thermomagnetic curves with high Tc around $580^{\circ} \mathrm{C}$ (Figs $6 \mathrm{~h}$ and $\mathrm{k}$ ) indicating the presence of magnetite and low $\mathrm{Tc}\left(200^{\circ} \mathrm{C}\right.$; Fig. $\left.5 \mathrm{k}\right)$ indicating Ti-mag with high Ti content.

High-field experiments of IRM acquisition curves, hysteresis loops and FORC diagrams revealed three different behaviours in our sample collection (Fig. 7). In the first one, seven sites present IRM curves saturating at fields around $0.2 \mathrm{~T}$ (e.g. Fig. 7a); hysteresis loops for these samples exhibit coercivities $<10 \mathrm{mT}$ (Fig. 7b) and FORC diagrams (Fig. 7c) are typical of MD grains. This behaviour is observed on COP01, COP03, COP05, COP20 (Cola de Zorro Fm.), COP10 (Upper Lavas, Las Mellizas Fm.), COP28 (Lower Lavas, Las Mellizas Fm.) and COP29 (Riscos Bayos Fm.). The second one is observed on 15 sites presenting IRM curves with saturating fields at around $0.25 \mathrm{~T}$ (Fig. $7 \mathrm{~d}$ ), coercivities between 10 and $20 \mathrm{mT}$ (Fig. 7e) and FORC diagrams characteristic of magnetite with PSD structure or mixtures of SD and MD magnetite grains. (Fig. 7f). Finally, the third behaviour comprises seven sites where IRM curves show saturating fields $\geq 0.3 \mathrm{~T}$ (Figs $7 \mathrm{~g}$ and $\mathrm{j}$ ), coercivities are between 20 and $35 \mathrm{mT}$ (Figs $7 \mathrm{~h}$ and $\mathrm{k}$ ) and FORC diagrams are typical of SD grains (Figs $7 \mathrm{i}$ and 1). This last behaviour is observed on COP12, COP14, COP22, COP32 (Ignimbrites, Las Mellizas Fm.), COP09, and COP16 (Upper Lavas, Las Mellizas Fm.) and COP23 (Riscos Bayos Fm.).

\subsection{Magnetic fabric}

\subsubsection{AMS fabric}

Histograms of mean magnetic susceptibility $\left(K_{\mathrm{m}}\right)$ (Fig. 8a) show different distributions for the three studied units. Samples from Las Mellizas Fm. presented a bimodal distribution, with lower values around $9-17 \times 10^{-3}$ SI and higher values at $20-33 \times 10^{-3} \mathrm{SI}$. This bimodal distribution is unrelated to the rock type since both lavas and welded ignimbrites have representative samples in the two ranges of susceptibility. Samples from Riscos Bayos ignimbrites are characterized by the lowest susceptibility values among the studied formations, around $3-16 \times 10^{-3} \mathrm{SI}$ (average of $\sim 4.2 \times 10^{-3} \mathrm{SI}$ ). Cola de Zorro Fm. show a wide-range distribution of magnetic susceptibility within $9-45 \times 10^{-3} \mathrm{SI}$ (average of $\sim 15.5 \times 10^{-3} \mathrm{SI}$ ), the highest values $\left(>30 \times 10^{-3}\right)$ correspond to site COP20, located in the northeast of the Caviahue Depression. The large variation in susceptibility values of the three studied formations may be linked to their magnetic mineral content. Also, most values are larger than $10^{-2}$ SI (except in Riscos Bayos Fm.), which can be attributed to the dominance of the ferromagnetic fraction in a bulk arrangement of studied rocks (Tarling \& Hrouda 1993).

The degree of anisotropy is low in all samples, reaching values up to 5 per cent (average of 1.5 per cent), as is commonly found for ignimbrites and volcanic rocks (Tarling \& Hrouda 1993; Agrò et al. 2015). The studied formations show a clear distinction in their magnetic susceptibilities. But there is no clear correlation between magnetic susceptibility and the degree of anisotropy within each unit (Fig. 8b), except for the Cola de Zorro collection, which presents a slight direct correlation between these two parameters. Of the 430 analysed samples, 300 are in the oblate field (121 with $T>0.5)$ and 130 in the prolate one ( 42 with $T<0.5$ ). Therefore, most anisotropy ellipsoids have a strongly triaxial to slightly oblate shape (Fig. 8c). 

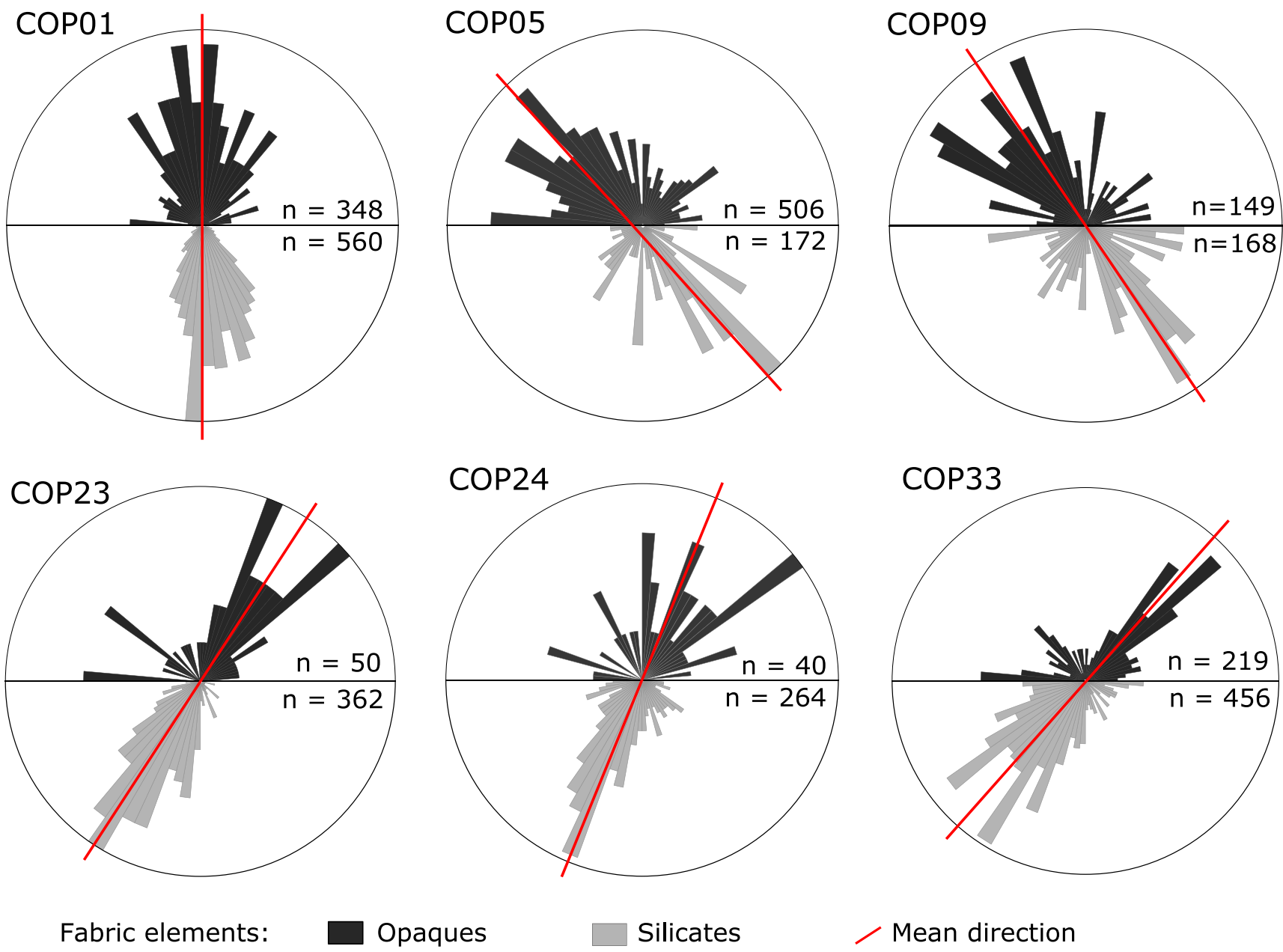

\section{Mean direction}

Figure 4. Rose diagrams showing the directions of major axis of opaque and silicate crystals.

The AMS directional data were analysed through the distribution of the main susceptibility axes within the lower hemisphere of equalarea stereonets (Fig. 9). The spatial orientation and clustering of each axis were statistically evaluated by principal directions of mean tensor and the semi-angles of their 95 per cent confidence ellipses, $E_{1-2}$ and $E_{2-3}$ (Jelínek \& Kropáček 1978). For each site, the magnetic lineation $\left(K_{1}\right)$ and foliation pole $\left(K_{3}\right)$ were not considered, respectively, when $E_{1-2}$ and $E_{2-3}$ were higher than $26^{\circ}$ (Jelínek $\&$ Kropáček 1978). That is, the directional data were summarized as high scattered and no statistical interpretation was performed neither the specimen nor the site level.

In the lava formations (white stereonets), four sites (COP04, COP06, COP16 and COP19) present low grouping of AMS principal directions of individual samples. These sites correspond to those with the lowest Tc values $\left(200^{\circ} \mathrm{C}\right.$; Fig. 6). For sites that passed the selection criteria above, the fabrics were grouped into 'normal', 'inverse' or 'intermediate' (Fig. 10a) according to bedding plane. The normal fabric was observed in six sites (COP03, COP10, COP17, COP21, COP28 and COP33) and the inverse fabric was observed in the site COP09. Intermediate fabric was not observed, and sites COP01, COP02, COP05 and COP20 presented anomalous fabrics that do not fall in any definition given in Fig. 10. Concerning the orientation of the magnetic lineation, each unit presented a different behaviour. In the Cola de Zorro Fm., magnetic lineation presents W$\mathrm{E}$ (COP02, COP20) and SW-NE (COP03) directions. Las Mellizas Upper Lavas exhibit magnetic lineation with variable directions: $\mathrm{N}-$ S (COP10), W-E (COP17) and SW-NE (COP21). For Las Mellizas Lower Lavas, the magnetic lineation present SW-NE (COP28) and W-E (COP33) directions.

In the ignimbrites (grey stereonets), poorly defined fabrics were observed in three sites (COP24, COP26 and COP27). The other sites present well-defined magnetic foliations with a sub-vertical pole $\left(K_{3}\right)$. These fabrics were grouped in 'parallel', 'transverse' and 'oblique' (Fig. 10b) according to the imbrication direction (e.g. Agrò et al. 2015). The parallel fabric was found in six sites (COP07, COP11, COP13, COP25, COP29 and COP30), transverse in four sites (COP08, COP12, COP22 and COP23) and oblique in the site COP32. For the ignimbrites from Las Mellizas Fm., four sites present imbrication on their magnetic foliation indicating mass transport towards NE or N (COP07, COP11, COP12 and COP13) with inclinations varying from $10^{\circ}$ to $35^{\circ}$ (Fig. 9). Other sites show imbrication towards E (COP32), SW (COP08) and $\mathrm{S}$ (COP22). In the ignimbrites from Riscos Bayos Fm., all sites (COP23, COP25, COP29 and COP30) present a well-defined fabric with imbrication towards $\mathrm{SE}$ and inclinations between $15^{\circ}$ and $30^{\circ}$ (Fig. 9). 

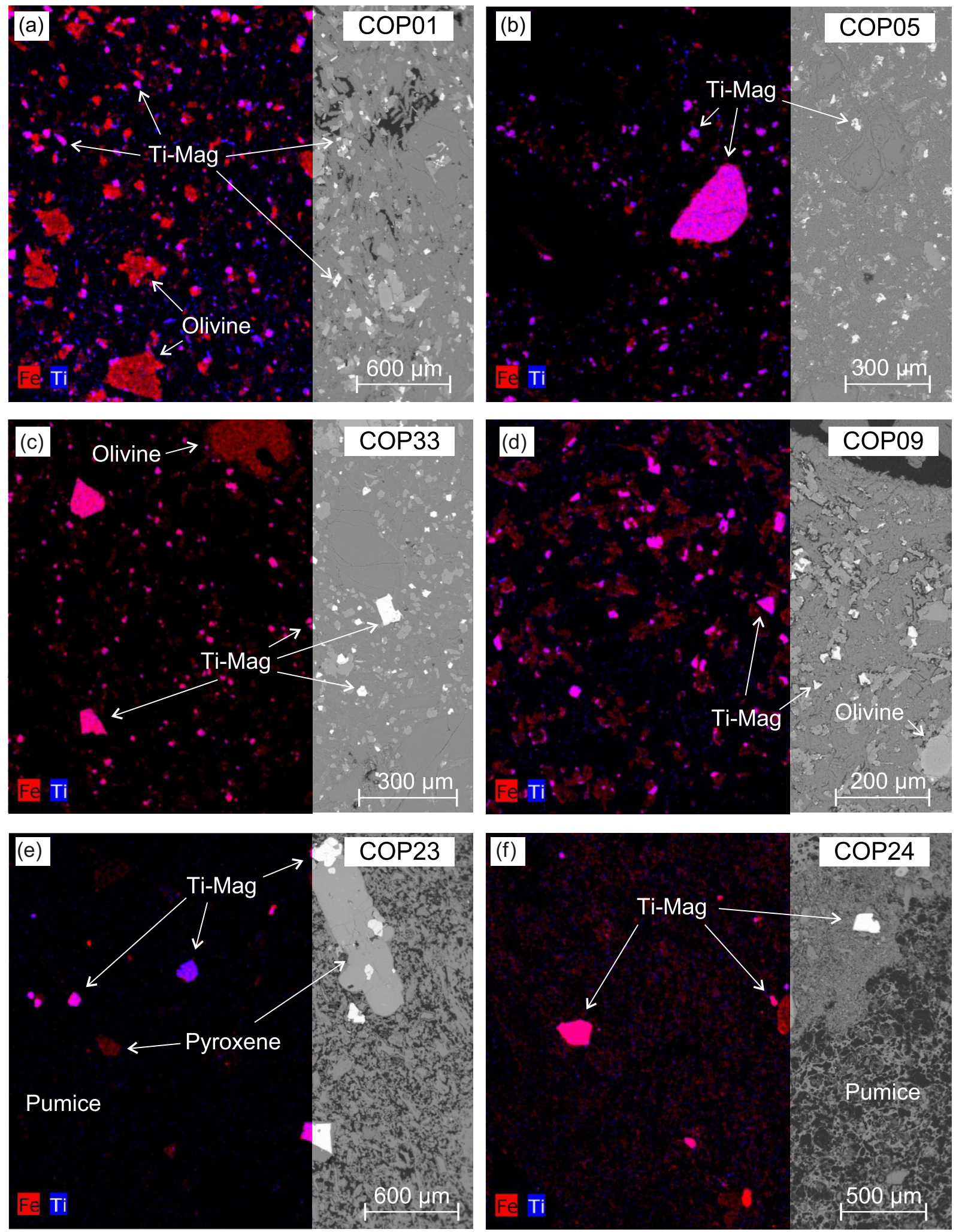

Figure 5. Mosaic of representative X-ray compositional maps (Fe and Ti) and BSE images showing major silicates (grey) and oxide (bright white) distribution. (a, b) Cola de Zorro Fm. (c) Las Mellizas Fm. - Lower lavas. (d) Las Mellizas Fm. - Upper lava. (e, f) Riscos Bayos Fm.

\subsubsection{AARM fabric}

Coercivity spectra (Fig. 11) shows two different behaviours, one comprising samples with low-coercivity grains (red curves) and other with both low- and high-coercivity grains (black curves).
Directional ARM was subsequently imparted using AC field of $100 \mathrm{mT}$ to cover most of the grain-size populations. In the 16 sites analysed by AARM (Table 1 and Fig. 9), the anisotropy significance was evaluated through the confidence angles $E_{1-2}\left(17^{\circ}\right.$ 

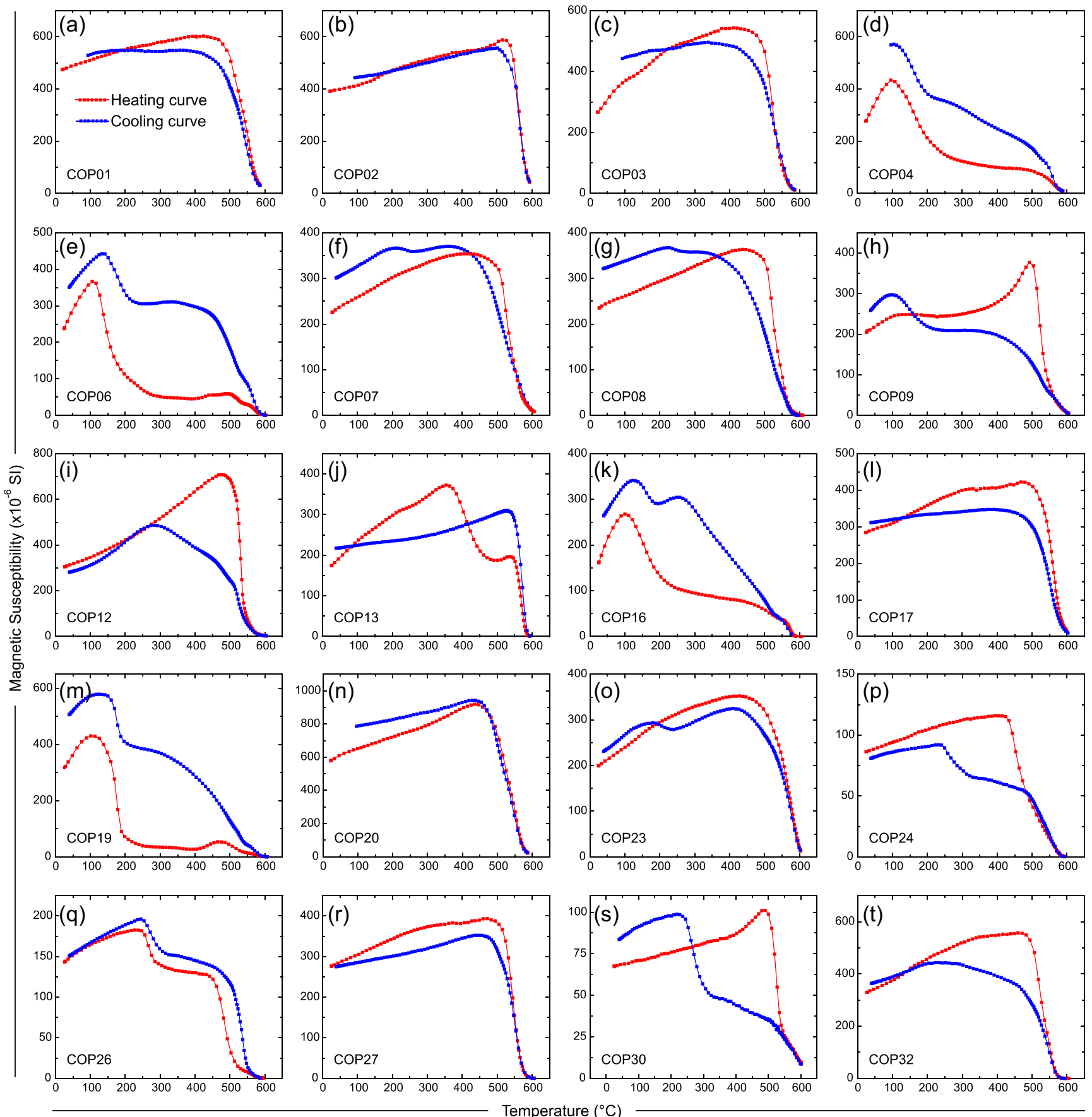

Figure 6. Thermomagnetic curves for individual rock types. Full heating curve (red) and cooling curve (blue) were obtained heating from room temperature up to $600{ }^{\circ} \mathrm{C}$ and cooling again to room temperature. Powdered samples were heated in air atmosphere.

to $\left.40^{\circ}\right), E_{2-3}\left(3^{\circ}\right.$ to $\left.15^{\circ}\right)$ and $E_{1-3}\left(5^{\circ}\right.$ to $\left.27^{\circ}\right)$. Sites COP02, COP03, COP07, COP08, COP11, COP12, COP13, COP22, COP23, COP28, COP29 and COP32 presented parallel AMS and AARM axes, suggesting that multidomain Ti-mag dominates the magnetic anisotropy. Sites COP08, COP09 and COP23 showed anomalous fabrics with an exchange between susceptibility and anhysteretic remanence main axes. Particularly, for site COP09 an inverse correlation is observed, with the maximum remanence axis $\left(M_{1}\right)$ being nearly horizontal and parallel to the minimum susceptibility axis $\left(K_{3}\right)$. No correlation was observed in sites COP04, COP14 and COP16.

\section{DISCUSSION}

Directional differences and the scatter of the AMS signal in the ignimbrites studied here have been previously associated with geological/geomorphological macroscopic factors, such as flow regime, topographical irregularities and the distance from the volcanic centre (e.g. Ort et al. 2015). It has also been shown that even in rocks with high bulk susceptibility, such as the ones studied here, the anisotropy of susceptibility can be carried by minerals other than magnetite (e.g. Rochette \& Vialon 1984; Hounslow 1985; Borradaile 1987; Rochette et al. 1992; Hirt et al. 1995). In our case, we compare the anisotropy of susceptibility and the anisotropy of 

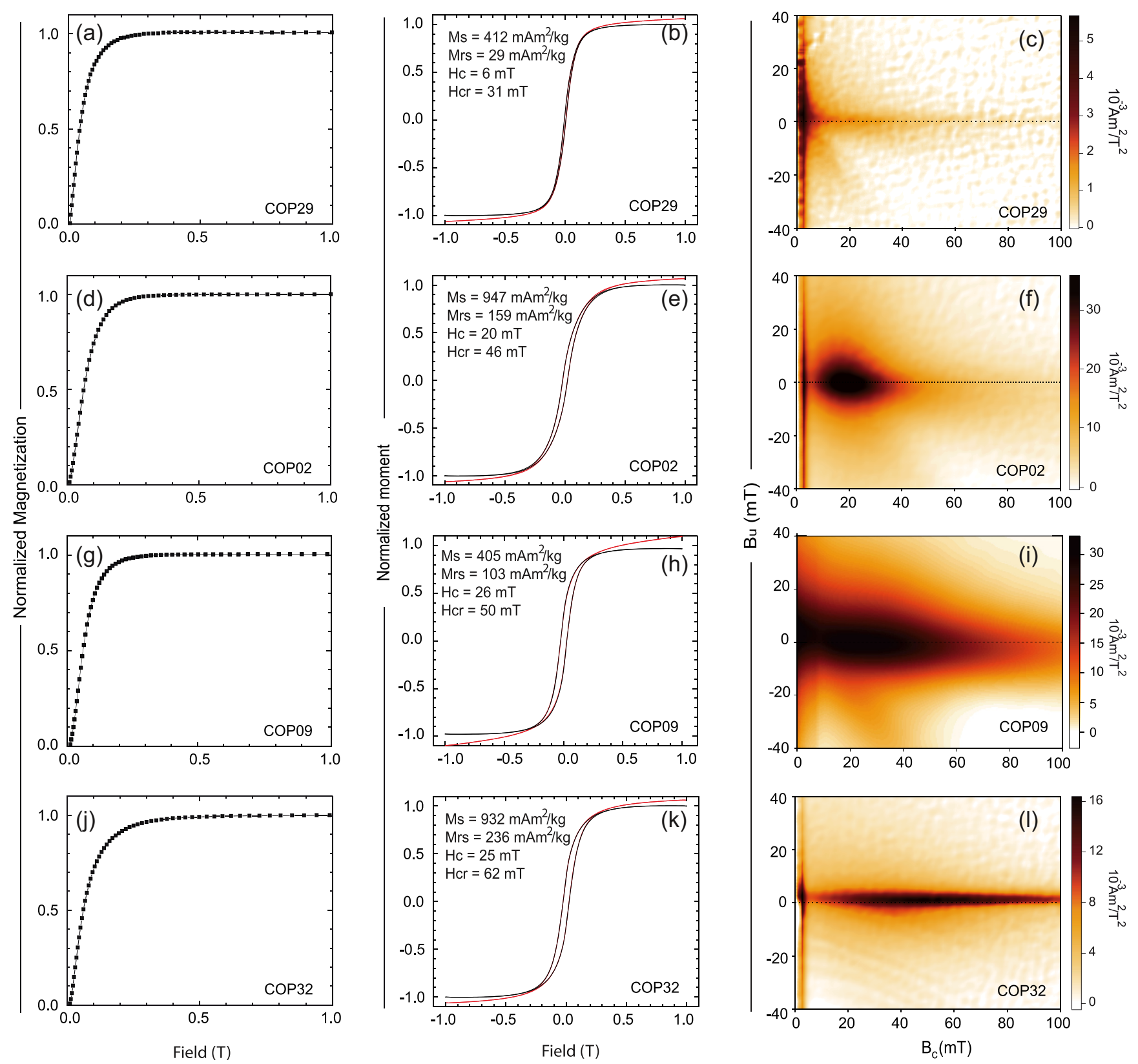

Figure 7. IRM acquisition curves, hysteresis loops and FORC diagrams. (a, d, g and j) representative IRM curves for sites COP29, COP02, COP09 and COP32. (b, e, h and $\mathrm{k}$ ) represents three characteristic hysteresis loops with respective coercivity and magnetization parameters, where red loops represent uncorrected para- and diamagnetic data. The hysteresis parameters are inside the graphics. (c, f, i and l) FORC diagrams for the same samples (smoothing factor 3-5), which (c) is typical of MD, (f) PSD, and (i and l) SD grains.

remanence and showed that they are compatible with almost all sites except for those where a high proportion of SD grains is observed. We then explore the possibility that even when magnetite carries most of the anisotropy in rocks, microscopic factors such as the order of crystallization of magnetic carriers, their grain-size and composition may exert a strong influence on the AMS signal, even for sites with well-defined macroscopic structures (e.g. magmatic foliation).

Field and petrographic analyses indicate well-oriented silicate fabrics for the studied units (Fig. 4), with two different textures of titanomagnetite in lavas and ignimbrites. The first one is characterized by straight-edge idiomorphic crystals often included in plagioclase phenocrysts (Fig. 5c) and the second by xenomorphic crystals with rounded edges (Fig. 5b). The thermomagnetic curves for sites showing exclusively idiomorphic, small magnetite crystals exhibit Curie temperatures near to $580-600{ }^{\circ} \mathrm{C}$, which indicates low-Ti titanomagnetites or pure magnetites as the main magnetic carriers in these rocks, not necessarily implying Ti-mag as the main carriers of the magnetic fabric. The AMS in those sites is well-defined, with well-grouped susceptibility axes, with exception to sites with a very low degree of anisotropy (Fig. 12). These results suggest a primary origin for the low-Ti titanomagnetites (to pure magnetites) and that the crystallization of the magnetic carriers occurred in the early stage of magma evolution, resulting in an effective orientation of Ti-mag in concordance with the flow-induced strain (Fig. 13a). 

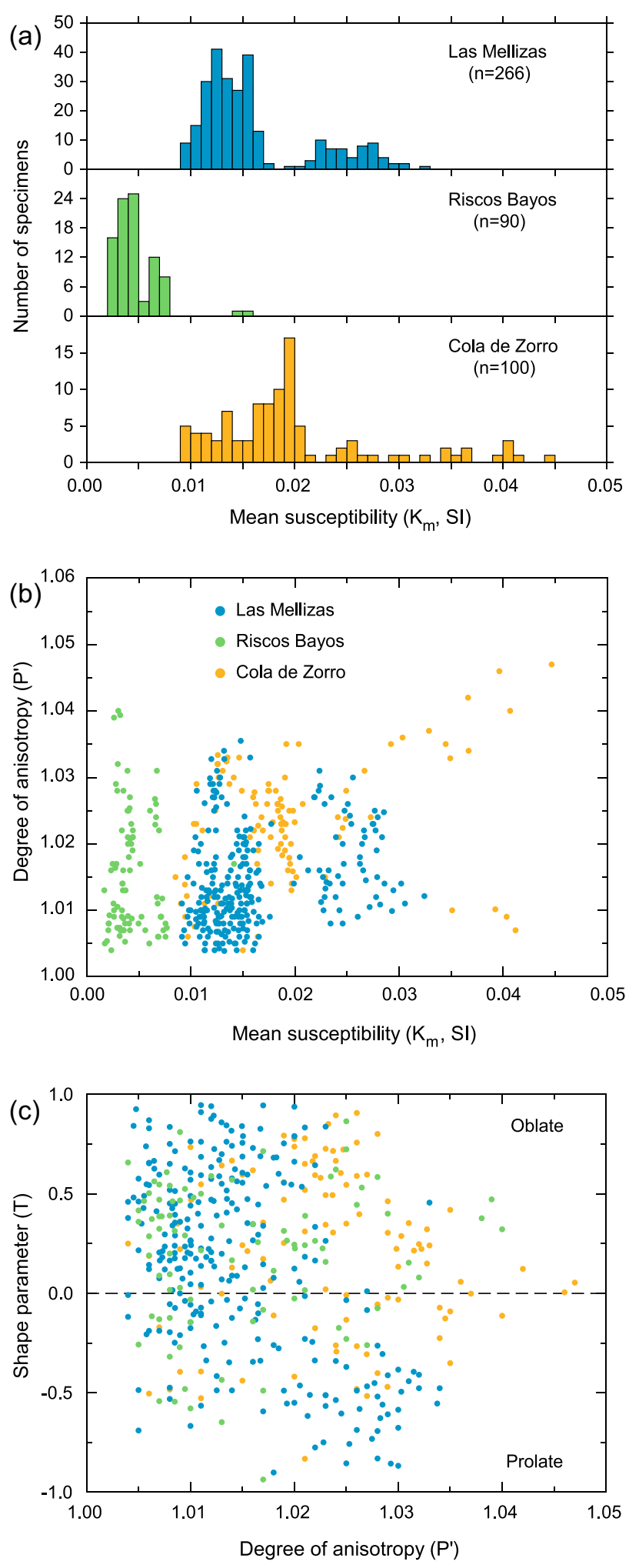

Figure 8. AMS scalar results. (a) Histograms with mean magnetic susceptibility $\left(K_{\mathrm{m}}\right)$; (b) Degree of anisotropy (P') and the mean magnetic susceptibility $\left(K_{\mathrm{m}}\right)$; (d) Jelinek's plot relating the shape parameter $(\mathrm{T})$ and the degree of anisotropy (P').
On the other hand, the magnetic results for samples with xenomorphic oxide crystals systematically show thermomagnetic curves with low Curie temperature $\left(\sim 200^{\circ} \mathrm{C}\right)$, suggesting highconcentrations of Ti in the titanomagnetites (e.g. Dunlop \& Özdemir 1997). Mineral texture in petrographic and SEM observations suggest that these titanomagnetites formed late in the history of magma crystallization, occupying the interstices left by the early crystallized minerals (Figs $13 \mathrm{~b}$ and c). Under these conditions, the magnetic fabric varies from well to poorly defined, depending on whether the late Ti-mag crystallization occurred in concordance with the pre-existing silicate fabric or not (Hargraves et al. 1991). In several sites, we observe a concordance between late, high-Ti titanomagnetite crystals and the silicate fabrics (e.g. site COP5), where these crystals form along the main axis of elongated silicate crystals (e.g. plagioclase and pyroxene) resulting in a well-defined AMS tensor (Fig. 13b). In contrast, there is a second group of sites with late Ti-mag crystals displaying incoherent orientation with the silicate fabrics. In this case, late crystals form randomly, not following the main silicate fabrics and yielding poorly defined AMS results (Fig. 13).

Another factor that may control the AMS is the domain structure of titanomagnetites. Rocks with MD Ti-mag may display a normal AMS fabric since its magnetization is dominantly governed by selfdemagnetization and shape anisotropy. In contrast, elongated small SD Ti-mag grains will show an inverse AMS fabric, because the magnetization in these grains is saturated along the easy axis. This will result in an exchange between the long axis of the crystal and the maximum AMS axis (Fig. 13d; Rochette 1987; Rochette et al. 1992). But intermediate AMS fabrics may arise when mixing small SD and large MD grains in the same rock. Ferré et al. (2002) and Ferré (2002) demonstrate that different mixtures of SD-MD Ti-mag grains result in intermediate fabrics. Although this kind of fabric can be observed by a contribution of different minerals, when Timag dominates the fabric the magnetic lineation does not reflect the flow direction, and there is no straightforward relationship between the shape or degree of the anisotropy and rock texture.

Sites of lava flow with a typical MD Ti-mag shows a 'normal' magnetic fabric and parallel AMS and AARM main axes. On the other hand, the site with a dominant SD behaviour (COP09) shows an 'inverse' magnetic fabric, where $K_{1}$ is parallel to the $M_{3}$ axis of the AARM tensor (Fig. 9). This is commonly associated with the 'SD effect' that has been long discussed in studies of magnetic anisotropy (Potter \& Stephenson 1988; Rochette et al. 1999), but its experimental observation is rare due to other factors that can also generate this type of fabric (Tarling \& Hrouda 1993; Chadima et al. 2009; Cañón-Tapia \& Mendoza-Borunda 2014). Here, the combined study of AMS and AARM allows us to eliminate this ambiguity, once SD Ti-mag (the main magnetic carrier observed in our sample collection) present magnetic fabric whose axis of maximum remanence is parallel to the minimum susceptibility. The petrographic analysis of site COP09 exhibits disseminated Fe-Ti oxides less than $2 \mu \mathrm{m}$ diameter, reinforcing the presence of SD Ti-mag (see Supporting Information Table ST1).

In the ignimbrite samples, the magnetic domain structure factor may also have affected the magnetic fabric. FORC diagrams with MD behaviour are exclusively related to 'parallel' fabric, whereas FORC diagrams with mixtures of MD-SD grains are linked to 'transverse' fabric. This fabric has been associated with very intense crystal-bearing pyroclastic fluxes by other authors (Giordano et al. 2008; Ort et al. 2013; Agrò et al. 2015; Ort et al. 2015). However, the 'SD effect' also occurs in the ignimbrites. It may produce a 

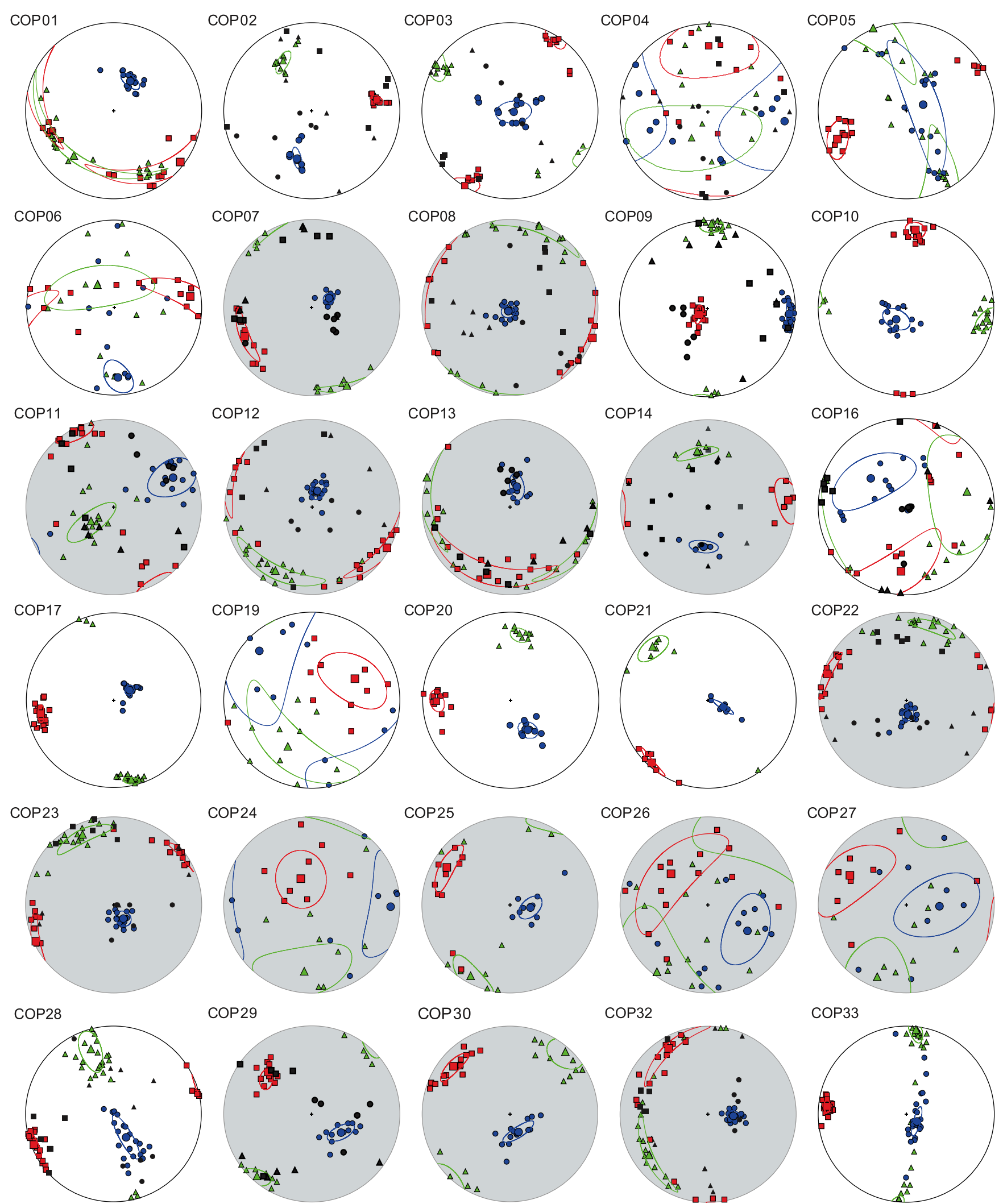

COP29

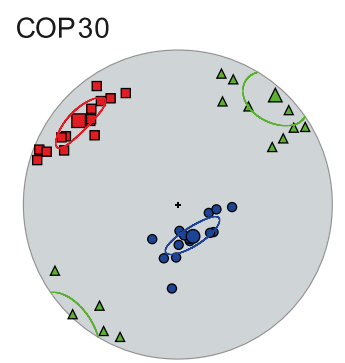

COP32
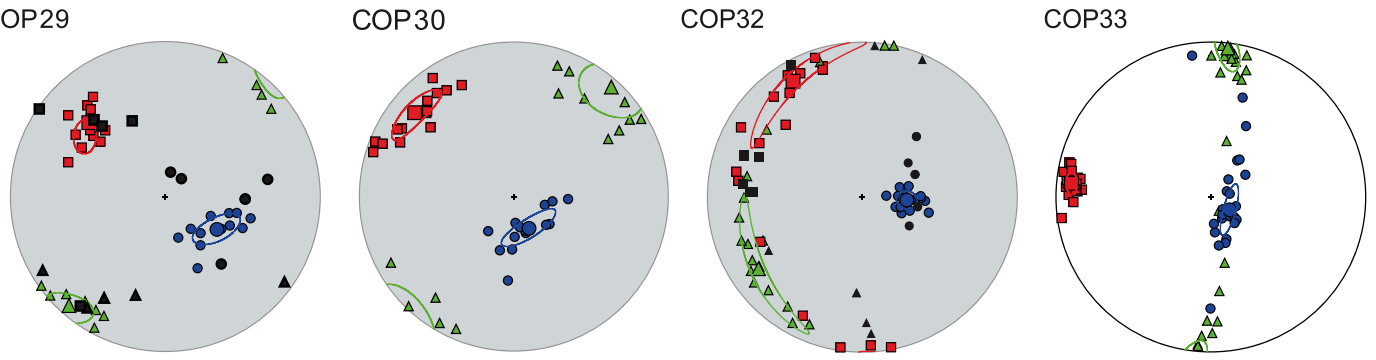

ASM: $\square \mathrm{K}_{1}, \Delta \mathrm{K}_{2}, \mathrm{~K}_{3}$

AARM: $\| \mathrm{M}_{1}, \Delta \mathrm{M}_{2}, \bullet \mathrm{M}_{3}$

Figure 9. Stereonets with main axes of AMS $\left(K_{1}>K_{2}>K_{3}\right)$ and AARM $\left(M_{1}>M_{2}>M_{3}\right)$ for all studied sites. The red squares represent $K_{1}$, green triangles $K_{2}$, blue dots $K_{3}$, black squares $M_{1}$, triangles $M_{2}$ and dots $M_{3}$. The grey and white stereonets correspond respectively to ignimbrite and lava formations. 
(a) Magnetic fabric of lavas - Classification related to the bedding plane

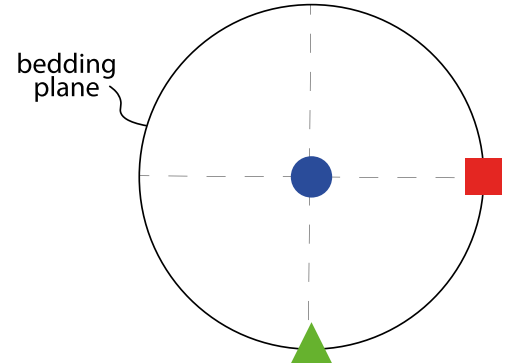

Normal

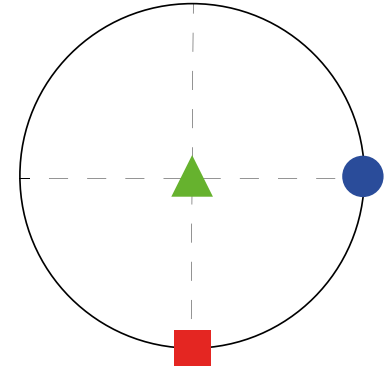

Intermediate

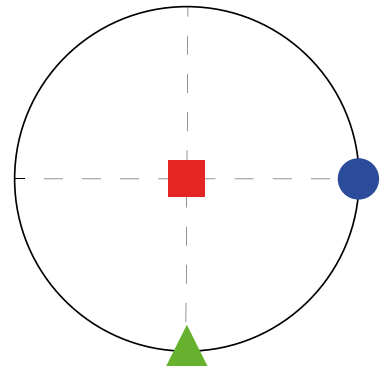

Inverse

(b) Magnetic fabric of ignimbrites - Classification related to the imbrication direction

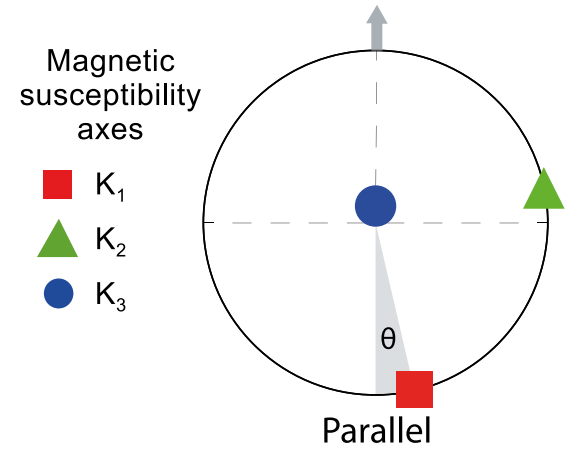

$\left(\theta<35^{\circ}\right)$

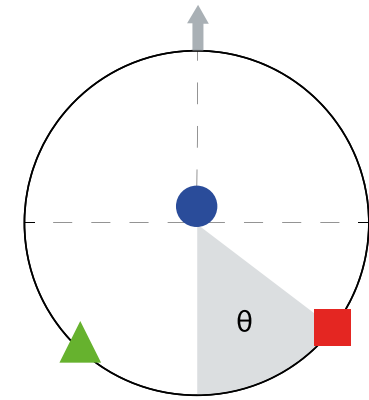

Oblique

$\left(35^{\circ}<\theta<55^{\circ}\right)$

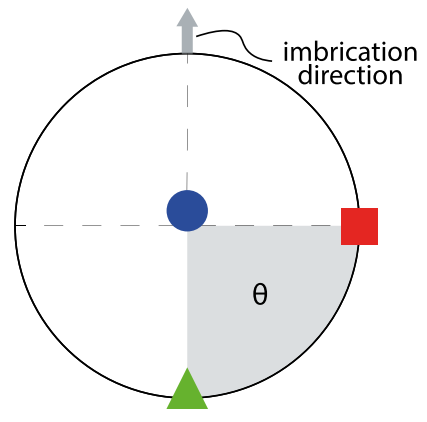

Transverse

$\left(\theta>55^{\circ}\right)$

Figure 10. Classification of magnetic fabric. (a) different fabrics found in lava flows, defined as normal, intermediate and inverse according to the bedding plane. (b) fabrics found in ignimbrites, defined as parallel, oblique and transverse according to de imbrication direction of the foliation plane (e.g. Agrò et al. 2015).

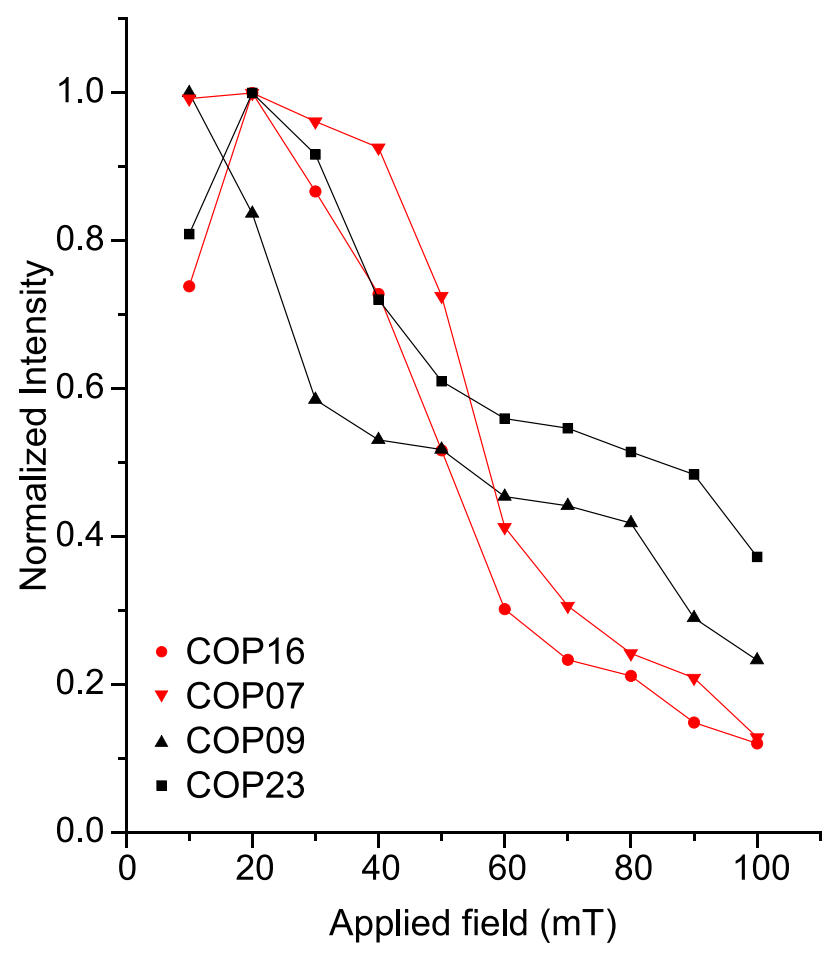

Figure 11. Coercivity spectra for samples with unimodal (red curves) and bimodal (black curves) distributions of coercivities.

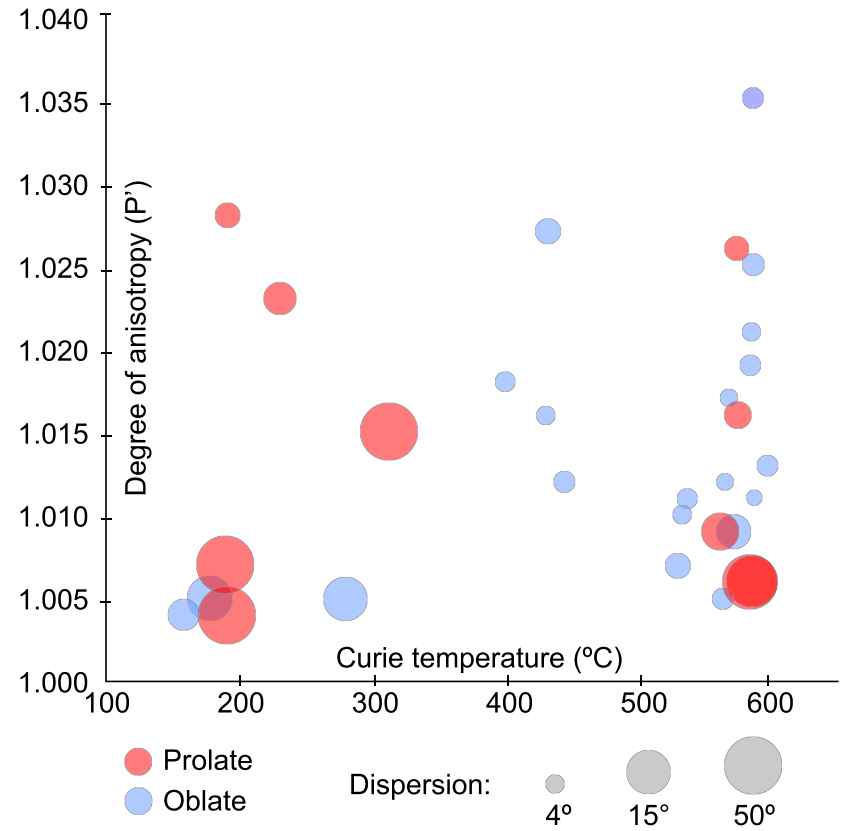

Figure 12. Comparison among the curie temperatures, shape parameter and the dispersion of the measured sites. Dispersion is expressed through $\mathrm{E}_{1-2}$ for prolate sites and $\mathrm{E}_{2-3}$ for oblate sites. 


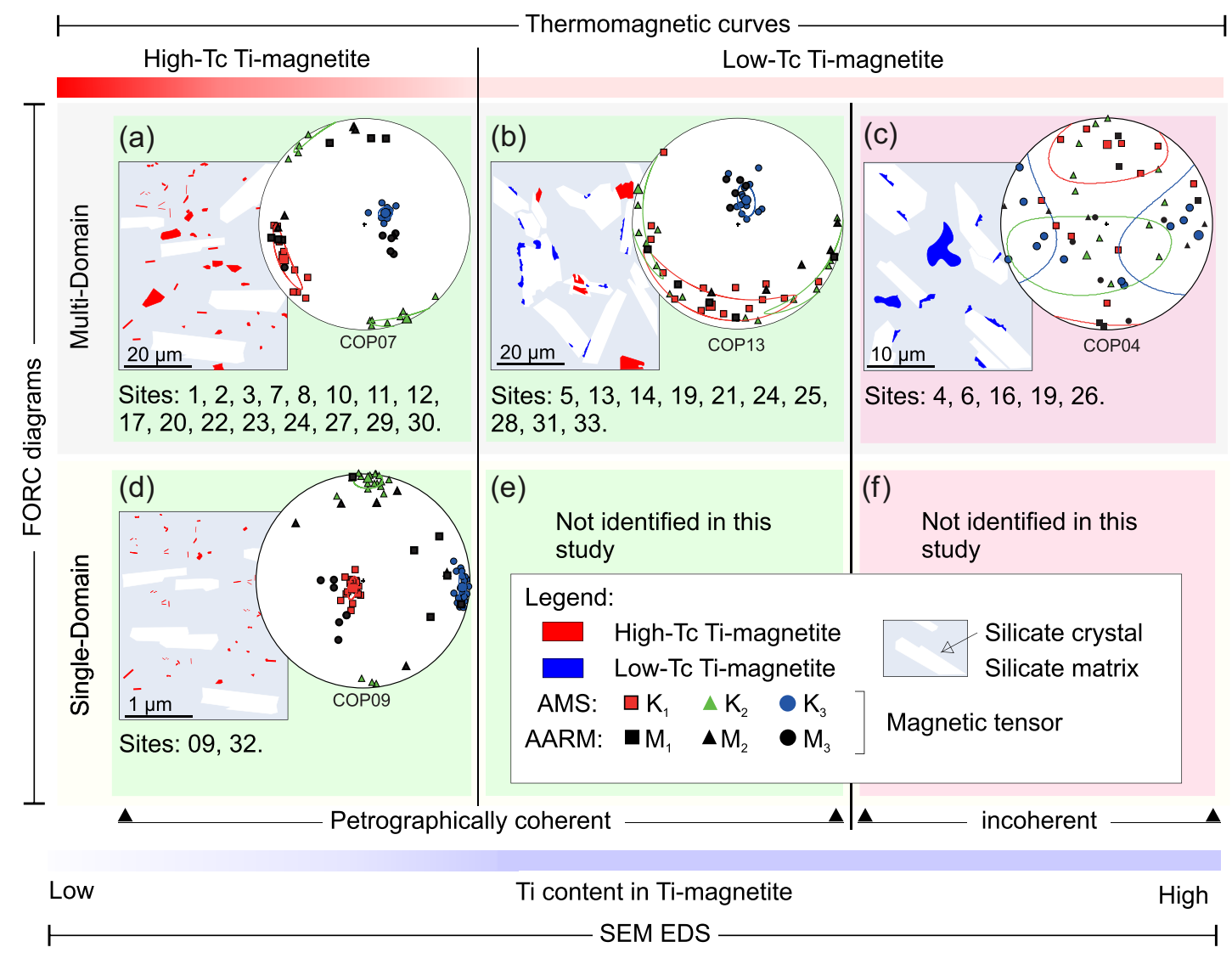

Figure 13. A summary of the AMS possibilities resulting from the combination of various scenarios: (a) MD, petrographically coherent crystals with high-Tc values; (b) MD, petrographically coherent crystals with low-Tc values; (c) MD, petrographically incoherent crystals low-Tc values; (d) SD, petrographically coherent crystals with high-Tc values; (e) SD, petrographically coherent crystals with low-Tc values; (f) SD, petrographically incoherent crystals low-Tc values.

transverse fabric that is not related to the flow regime, but instead to the composite fabrics of SD and MD magnetite grains present in the same site. Thus, any geological interpretation from AMS data should carefully consider the carriers of magnetic anisotropy and not only macroscopic factors.

\section{CONCLUSIONS}

The comparison between petrographic properties, rock magnetism, and magnetic anisotropies revealed that the CVCC extrusive and pyroclastic rocks present varied magnetic mineralogy, formed in different stages of the magmatic evolution. Some sites are characterized by idiomorphic magnetite crystals of pure magnetite or low-Ti titanomagnetites, with elevated Curie temperature. Other sites present high-Ti titanomagnetites with irregular forms, typical of late crystallization. Also, there is a great granulometric variation in the titanomagnetite crystals, with a predominance of large MD crystals in some sites and SD crystals in others. In all cases, titanomagnetite dominates the magnetic fabric of the rocks. The sites with late-crystallized high-Ti titanomagnetite have an undefined fabric $\left(E_{1-2}, E_{2-3}>26^{\circ}\right)$, while the sites with early-crystallized magnetite and low-Ti titanomagnetite have well-defined magnetic fabric. This probably occurs because the earliest minerals register the magma flow (or the pyroclastic flux in the case of ignimbrites). Among the sites with pure magnetite or low-Ti titanomagnetite, some have a significant amount of crystals with SD domain structure. In one of these sites, the fabric has an inverse behaviour (e.g.
COP09), showing perpendicular AMS and AARM fabrics. Further AARM measurements at sites where SD grains were identified will be required to determine the influence of these grains on the final AMS fabric, eventually producing intermediate fabric orientations. This work demonstrates the complexity in the interpretation of magnetic anisotropy data in volcanic rocks, suggesting that such studies need to be accompanied by a detailed investigation of the magnetic mineralogy, and the minerals carrying the magnetic fabrics.

\section{ACKNOWLEDGEMENTS}

This work was supported by CNPq grant 144580/2016-0 to TRM, CAPES AUXPE 2043/2014 and CNPq grant 454609/20140 to GAH, CNPq/CAPES grant 400724/2014-6 and CNPq grants 441766/2014-5 and 303015/2015-2 to CAS. We thank D. Brandt, G. Moreira e P. Jaqueto by the support during sample preparation and data acquisition. We thank two anonymous reviewers for their helpful and constructive comments.

\section{REFERENCES}

Agrò, A., Zanella, E., Le Pennec, J.-L. \& Temel, A., 2015. Magnetic fabric of ignimbrites: a case study from the Central Anatolian Volcanic Province, Geol. Soc. London, 396(1), 159-175.

Archanjo, C.J. \& Launeau, P., 2004. Magma flow inferred from preferred orientations of plagioclase of the Rio Ceará-Mirim dyke swarm (NE Brazil) and its AMS significance, Geol. Soc. London, 238(1), 285-298. 
Bascou, J., Camps, P. \& Dautria, J.M., 2005. Magnetic versus crystallographic fabrics in a basaltic lava flow, J. Volc. Geotherm. Res., 145(1-2), 119-135.

Biedermann, A.R., Lowrie, W. \& Hirt, A.M., 2013. A method for improving the measurement of low-field magnetic susceptibility anisotropy in weak samples, J. appl. Geophys., 88, 122-130.

Borradaile, G., 1987. Anisotropy of magnetic susceptibility: rock composition versus strain, Tectonophysics, 138(2-4), 327-329.

Borradaile, G. \& Henry, B., 1997. Tectonic applications of magnetic susceptibility and its anisotropy, Earth-. Sci. Rev., 42(1-2), 49-93.

Borradaile, G.J. \& Jackson, M., 2010. Structural geology, petrofabrics and magnetic fabrics (AMS, AARM, AIRM), J. Struct. Geol., 32(10), 15191551.

Cañón-Tapia, E., 2004. Flow direction and magnetic mineralogy of lava flows from the central parts of the peninsula of Baja California, Mexico, Bull. Volcanol., 66(5), 431-442.

Cañón-Tapia, E. \& Mendoza-Borunda, R., 2014. Magnetic petrofabric of igneous rocks: Lessons from pyroclastic density current deposits and obsidians, J. Volc. Geotherm. Res., 289, 151-169.

Cañón-Tapia, E., Walker, G.P. \& Herrero-Bervera, E., 1995. Magnetic fabric and flow direction in basaltic pahoehoe lava of Xitle volcano, Mexico, $J$. Volc. Geotherm. Res., 65(3-4), 249-263.

Cañón-Tapia, E., Walker, G.P. \& Herrero-Bervera, E., 1996. The internal structure of lava flows-insights from AMS measurements i: near-vent a'a, J. Volc. Geotherm. Res., 70(1-2), 21-36.

Chadima, M., Cajz, V. \& Tỳcová, P., 2009. On the interpretation of normal and inverse magnetic fabric in dikes: examples from the Eger Graben, NW Bohemian Massif, Tectonophysics, 466(1-2), 47-63.

Cole, J., Milner, D. \& Spinks, K., 2005. Calderas and caldera structures: a review, Earth-Sci. Rev., 69(1-2), 1-26.

Day, R., Fuller, M. \& Schmidt, V., 1977. Hysteresis properties of titanomagnetites: grain-size and compositional dependence, Phys. Earth planet. Inter., 13(4), 260-267.

Dunlop, D. \&Özdemir, 1997. Rock magnetism: Fundamentals and Frontiers, Cambridge University Press, $573 p$.

Dunlop, D.J., 2002. Theory and application of the day plot (Mrs/Ms versus $\mathrm{Hcr} / \mathrm{Hc})$ 1. theoretical curves and tests using titanomagnetite data, $J$. geophys. Res., 107(B3), EPM-4.

Elston, W.E. \& Smith, E.I., 1970. Determination of flow direction of rhyolitic ash-flow tuffs from fluidal textures, Bull. geol. Soc. Am., 81(11), 33933406.

Ferré, E.C., 2002. Theoretical models of intermediate and inverse AMS fabrics, Geophys. Res. Lett., 29(7), 31-1.

Ferré, E.C., Bordarier, C. \& Marsh, J.S., 2002. Magma flow inferred from AMS fabrics in a layered mafic sill, Insizwa, South Africa, Tectonophysics, 354(1-2), 1-23.

Folguera, A. \& Ramos, V., 2000. Control estructural del volcán Copahue $\left(38^{\circ} \mathrm{S}-71^{\circ} \mathrm{O}\right)$ : implicancias tectónicas para el arco volcánico cuaternario (36-39 ${ }^{\circ}$ S), Rev. Asoc. Geol. Argentina, 53(3), 229-244.

Folguera, A., Ramos, V.A. \& Melnick, D., 2003. Recurrencia en el desarrollo de cuencas de intraarco.: Cordillera Neuquina $\left(37^{\circ} 30^{\prime}-38^{\circ} \mathrm{S}\right)$, Rev. Asoc. Geol. Argentina, 58(1), 3-19.

Folguera, A., Vera, E.R., Vélez, L., Tobal, J., Orts, D., Agusto, M., Caselli, A. \& Ramos, V., 2016. A review of the geology, structural controls, and tectonic setting of Copahue volcano, Southern Volcanic Zone, Andes, Argentina, in Copahue Volcano, pp. 3-22, eds Tassi, F., Vaselli, O. \& Caselli, A., Springer.

Geshi, N., Shimano, T., Chiba, T. \& Nakada, S., 2002. Caldera collapse during the 2000 eruption of Miyakejima Volcano, Japan, Bull. Volcanol., 64(1), 55-68.

Giordano, G., Porreca, M., Musacchio, P. \& Mattei, M., 2008. The Holocene Secche di lazzaro phreatomagmatic succession (Stromboli, Italy): evidence of pyroclastic density current origin deduced by facies analysis and AMS flow directions, Bull. Volcanol., 70(10), 1221-1236.

Graham, J., 1954. Magnetic anisotropy, an unexploited petrofabric element, Geol. soc. Am. Bull., 65, 1257-1258.

Groeber, P., 1925. La región de copahue y su glaciación diluvial, Soc. Argentina Estud. Geogr., 1(3), 92-110.
Gudmundsson, M.T. et al., 2016. Gradual caldera collapse at Bárdarbunga volcano, Iceland, regulated by lateral magma outflow, Science, 353(6296), aaf8988, doi: 10.1126/science.aaf8988.

Hargraves, R., Johnson, D. \& Chan, C., 1991. Distribution anisotropy: the cause of ams in igneous rocks? Geophys. Res. Lett., 18(12), 2193-2196.

Harrison, R.J. \& Feinberg, J.M., 2008. FORCinel: An improved algorithm for calculating first-order reversal curve distributions using locally weighted regression smoothing, Geochem.Geophys. Geosyst., 9(5), doi:10.1029/2008GC001987.

Hirt, A., Evans, K. \& Engelder, T., 1995. Correlation between magnetic anisotropy and fabric for devonian shales on the Appalachian Plateau, Tectonophysics, 247(1-4), 121-132.

Hounslow, M., 1985. Magnetic fabric arising from paramagnetic phyllosilicate minerals in mudrocks, J. Geol. Soc. 142(6), 995-1006.

Hrouda, F., 1982. Magnetic anisotropy of rocks and its application in geology and geophysics, Geophys. Surv., 5(1), 37-82.

Hrouda, F., 1994. A technique for the measurement of thermal changes of magnetic susceptibility of weakly magnetic rocks by the CS-2 apparatus and KLY-2 kappabridge, Geophys. J. Int., 118(3), 604-612.

Hrouda, F., 2003. Indices for numerical characterization of the alteration processes of magnetic minerals taking place during investigation of temperature variation of magnetic susceptibility, Stud. Geophys. Geod., 47(4), $847-861$.

Jackson, M., 1991. Anisotropy of magnetic remanence: a brief review of mineralogical sources, physical origins, and geological applications, and comparison with susceptibility anisotropy, Pure appl. Geophys., 136(1), $1-28$.

Jelínek, V., 1977. The Statistical Theory of Measuring Anisotropy of Magnetic Susceptibility of Rocks and its Application, Geofyzika Brno.

Jelinek, V., 1981. Characterization of the magnetic fabric of rocks, Tectonophysics, 79(3-4), T63-T67.

Jelínek, V. \& Kropáček, V., 1978. Statistical processing of anisotropy of magnetic susceptibility measured on groups of specimens, Stud. Geophys. Geod., 22(1), 50-62.

Khan, M.A., 1962. The anisotropy of magnetic susceptibility of some igneous and metamorphic rocks, J. geophys. Res., 67(7), 2873-2885.

Kodama, K.P., 1995. Magnetic fabrics, Rev. Geophys., 33(S1), 129-135.

LaBerge, R.D., Porreca, M., Mattei, M., Giordano, G. \& Cas, R.A., 2009. Meandering flow of a pyroclastic density current documented by the anisotropy of magnetic susceptibility (AMS) in the quartz latite ignimbrite of the Pleistocene Monte Cimino volcanic centre (central Italy), Tectonophysics, 466(1-2), 64-78.

Linares, E., Ostera, H.A. \& Mas, L., 1999. Cronologia potasio-argon del complejo efusivo Copahue-Caviahue, Provincia del Neuquen, Rev. Asoc. Geol. Argentina, 54(3), 240-247.

MacDonald, W.D. \& Ellwood, B.B., 1987. Anisotropy of magnetic susceptibility: Sedimentological, igneous, and structural-tectonic applications, Rev. Geophys., 25(5), 905-909.

Magee, C., O'Driscoll, B., Petronis, M. \& Stevenson, C., 2016. Threedimensional magma flow dynamics within subvolcanic sheet intrusions, Geosphere, 12(3), 842-866.

Martín-Hernández, F., Lüneburg, C., Aubourg, C. \& Jackson, M., 2004. Magnetic fabric: methods and applications-an introduction, Geol. Soc. London, 238(1), 1-7.

Mazzoni, L. \& Licitra, D.T., 2000. Significado estratigráfico y volcanológico de depósitos de flujos piroclásticos neógenos con composición intermedia en la zona del lago Caviahue, Provincia del Neuquén, Rev. Asoc. Geol. Argentina, 55(3), 247-249.

Melnick, D., Folguera, A. \& Ramos, V.A., 2006. Structural control on arc volcanism: the Caviahue-Copahue complex, Central to Patagonian andes transition $\left(38^{\circ} \mathrm{S}\right), J$. South Am. Earth Sci., 22(1-2), $66-88$.

Muñoz, J. \& Stern, C., 1988. The Quaternary volcanic belt of the southern continental margin of South America: transverse structural and petrochemical variations across the segment between $38^{\circ} \mathrm{S}$ and $39^{\circ} \mathrm{S}, J$. South Am. Earth Sci., 1(2), 147-161. 
Ort, M.H., De Silva, S.L., Jiménez C, N., Jicha, B.R. \& Singer, B.S., 2013. Correlation of ignimbrites using characteristic remnant magnetization and anisotropy of magnetic susceptibility, Central Andes, Bolivia, Geochem. Geophys. Geosyst., 14(1), 141-157.

Ort, M.H., Newkirk, T., Vilas, J. \& Vazquez, J., 2015. Towards the definition of AMS facies in the deposits of pyroclastic density currents, Geol. Soc. London, 396(1), 205-226.

Pesce, A., 1989. Evolución volcano-tectónica del complejo efusivo Copahue-Caviahue y su modelo geotérmico preliminar, Rev. Asoc. Geol. Argentina, 44(1-4), 307-327.

Potter, D.K. \& Stephenson, A., 1988. Single-domain particles in rocks and magnetic fabric analysis, Geophys. Res. Lett., 15(10), 1097-1100.

Riel, B., Milillo, P., Simons, M., Lundgren, P., Kanamori, H. \& Samsonov, S., 2015. The collapse of Bárharbunga caldera, Iceland, Geophys. J. Int., 202(1), 446-453.

Roberts, A.P., Pike, C.R. \& Verosub, K.L., 2000. First-order reversal curve diagrams: A new tool for characterizing the magnetic properties of natural samples, J. geophys. Res., 105(B12), 28 461-28 475.

Roberts, A.P., Heslop, D., Zhao, X. \& Pike, C.R., 2014. Understanding fine magnetic particle systems through use of first-order reversal curve diagrams, Rev. Geophys., 52(4), 557-602.

Rochette, P., 1987. Magnetic susceptibility of the rock matrix related to magnetic fabric studies, J. Struct. Geol., 9(8), 1015-1020.

Rochette, P. \& Vialon, P., 1984. Development of planar and linear fabrics in Dauphinois shales and slates (French Alps) studied by magnetic anisotropy and its mineralogical control, J. Struct. Geol., 6(1-2), $33-38$.
Rochette, P., Jackson, M. \& Aubourg, C., 1992. Rock magnetism and the interpretation of anisotropy of magnetic susceptibility, Rev. Geophys., 30(3), 209-226.

Rochette, P., Aubourg, C. \& Perrin, M., 1999. Is this magnetic fabric normal? A review and case studies in volcanic formations, Tectonophysics, 307(12), 219-234.

Schindelin, J. et al., 2012. Fiji: an open-source platform for biological-image analysis, Nature Methods, 9(7), 676-682,

., Consoli,Sruoga P, C.V., 2011. El Volcán Copahue, in Congreso Geológico Argentino, Neuquén, Argentina, pp. 613-620.

Stephenson, A.,Sadikun,S.t. \& Potter, D., 1986. A theoretical and experimental comparison of the anisotropies of magnetic susceptibility and remanence in rocks and minerals, Geophys. J. Int., 84(1), 185-200.

Tarling, D. \& Hrouda, F., 1993. The Magnetic Anisotropy of Rocks, Chapman and Hall, London, UK, 217.

Tauxe, L., 1998. Paleomagnetic principles and practice. kluwer academic publishers, dordrecht (299pp.). rise and growth of the tibet plateau, Science, 294, 1671-1677.

Varekamp, J.C., deMoor, J.M., Merrill, M.D., Colvin, A.S., Goss, A.R., Vroon, P.Z. \& Hilton, D.R., 2006. Geochemistry and isotopic characteristics of the Caviahue-Copahue volcanic complex, Province of Neuquén, Argentina, Geol. Soc. Am., 407, 317.

Wiegand, M., Trumbull, R.B., Kontny, A. \& Greiling, R.O., 2017. An AMS study of magma transport and emplacement mechanisms in mafic dykes from the Etendeka Province, Namibia, Tectonophysics, 716, 149-167.

Wing-Fatt, L. \& Stacey, F.D., 1966. Magnetic anisotropy of laboratory materials in which magma flow is simulated, Pure appl. Geophys., 64(1), $78-80$. 